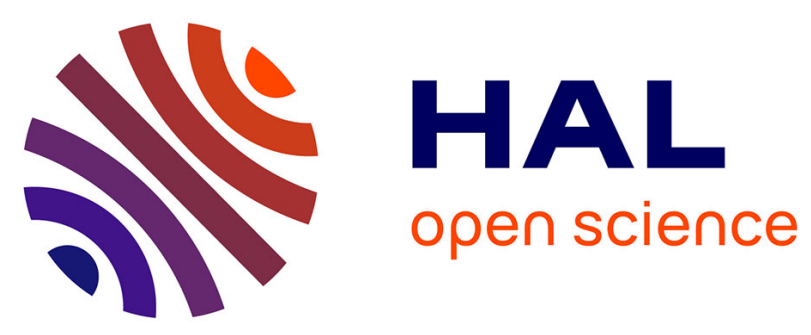

\title{
Maternal fine particulate matter exposure, polymorphism in xenobiotic-metabolizing genes and offspring birth weight.
}

Rémy Slama, Carolin Gräbsch, Johanna Lepeule, Valérie Siroux, Josef Cyrys, Stefanie Sausenthaler, Olf Herbarth, Mario Bauer, Michael Borte, H-Erich Wichmann, et al.

\section{To cite this version:}

Rémy Slama, Carolin Gräbsch, Johanna Lepeule, Valérie Siroux, Josef Cyrys, et al.. Maternal fine particulate matter exposure, polymorphism in xenobiotic-metabolizing genes and offspring birth weight.: Air pollution, genes and birthweight. Reproductive Toxicology, 2010, 30 (4), pp.600-12. 10.1016/j.reprotox.2010.07.001 . inserm-00503997

\section{HAL Id: inserm-00503997 https://www.hal.inserm.fr/inserm-00503997}

Submitted on 4 Apr 2011

HAL is a multi-disciplinary open access archive for the deposit and dissemination of scientific research documents, whether they are published or not. The documents may come from teaching and research institutions in France or abroad, or from public or private research centers.
L'archive ouverte pluridisciplinaire HAL, est destinée au dépôt et à la diffusion de documents scientifiques de niveau recherche, publiés ou non, émanant des établissements d'enseignement et de recherche français ou étrangers, des laboratoires publics ou privés. 


\section{Elsevier Editorial System(tm) for Reproductive Toxicology}

Manuscript Draft

Manuscript Number: 2719R1

Title: Maternal Fine Particulate Matter Exposure, Polymorphism in Xenobiotic-Metabolizing Genes and Offspring Birthweight

Article Type: Full Length Article

Keywords: Air pollution; Birth Weight; Epidemiology; Particulate Matter; Passive Smoking; Polymorphism, Genetic; Smoking

Corresponding Author: Dr. Remy Slama, Ph.D.

Corresponding Author's Institution: Inserm

First Author: Remy Slama, Ph.D.

Order of Authors: Remy Slama, Ph.D.; Carolin Gräbsch, PhD; Johanna Lepeule, PhD; Valérie Siroux, PhD; Josef Cyrys, PhD; Stefanie Sausenthaler, PhD; Olf Herbarth, PhD; Mario Bauer, PhD; Michael Borte, PhD; H-Erich Wichmann, PhD; Joachim Heinrich, PhD

Manuscript Region of Origin: GERMANY

Abstract: We aimed to describe if polymorphisms in xenobiotics-metabolizing genes modify the effect of maternal exposure to fine particulate matter (PM2.5) on offspring birthweight.

Among newborns from LISA cohort, we tested if polymorphisms of GSTT1, GSTP1, GSTM1, and CYP2D6 genes modified the effect measure of PM2.5 on term birthweight. Subsequently, we tested if polymorphisms modified the effect of other exposure factors with similar pathways of action (active or passive smoking).

PM2.5 exposure above the median value (reference, below) was associated with birthweight changes by $76 \mathrm{~g}$ in the homozygous wild type genotype $(\mathrm{n}=161),-90 \mathrm{~g}$ in the heterozygous genotype $(\mathrm{n}=154)$ and $-168 \mathrm{~g}$ in children with GSTP1 $* 1 B /{ }^{*} 1 \mathrm{~B}$ mutant genotype $(\mathrm{n}=39$, interaction test, $\mathrm{p}=0.05)$. No effect measure modification with PM2.5 was detected for GSTT1, GSTM1 or CYP2D6 polymorphisms $(\mathrm{p} \geq 0.12)$. No effect measure modification with GSTP1 polymorphism was detected for active $(\mathrm{p}=0.71)$ nor for passive smoking effects on birthweight $(\mathrm{p}=0.13)$. 


\section{Maternal Fine Particulate Matter Exposure, Polymorphism in Xenobiotic- Metabolizing Genes and Offspring Birthweight.}

Rémy Slama et al.

\section{ABSTRACT}

We aimed to describe if polymorphisms in xenobiotics-metabolizing genes modify the effect of maternal exposure to fine particulate matter $\left(\mathrm{PM}_{2.5}\right)$ on offspring birthweight.

Among newborns from LISA cohort, we tested if polymorphisms of GSTT1, GSTP1, GSTM1, and CYP2D6 genes modified the effect measure of $\mathrm{PM}_{2.5}$ on term birthweight. Subsequently, we tested if polymorphisms modified the effect of other exposure factors with similar pathways of action (active or passive smoking).

$\mathrm{PM}_{2.5}$ exposure above the median value (reference, below) was associated with birthweight changes by $76 \mathrm{~g}$ in the homozygous wild type genotype $(\mathrm{n}=161),-90 \mathrm{~g}$ in the heterozygous genotype $(\mathrm{n}=154)$ and $-168 \mathrm{~g}$ in children with GSTP1 ${ }^{*} 1 \mathrm{~B} /{ }^{*} 1 \mathrm{~B}$ mutant genotype $(\mathrm{n}=39$, interaction test, $\mathrm{p}=0.05)$. No effect measure modification with $\mathrm{PM}_{2.5}$ was detected for GSTT1, GSTM1 or CYP2D6 polymorphisms $(\mathrm{p} \geq 0.12)$. No effect measure modification with GSTP1 polymorphism was detected for active $(p=0.71)$ nor for passive smoking effects on birthweight $(p=0.13)$.

Key words: Air pollution; Birth Weight; Particulate Matter; Passive Smoking; Polymorphism, Genetic; Smoking. 


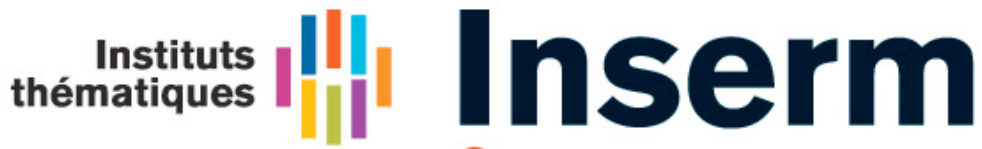 \\ Institut national \\ de la santé et de la recherche médicale
}

\author{
Rémy Slama \\ Team leader \\ Team 14
}

Environmental Epidemiology applied to

Fecundity and Reproduction

Inserm U. 823 / Institut Albert Bonniot

Phone: +33476 549402

remy.slama@ujf-grenoble.fr

\author{
Grenoble, 25 February 2010 \\ Thomas B. Knudsen \\ Editor-in-Chief \\ Reproductive Toxicology
}

Dear Editor,

We are pleased to submit to Reproductive Toxicology a revised version of our manuscript on gene-environment interactions in the context of the impact of atmospheric pollutants on birth weight.

This revised version takes into account the comments from both reviewers. In particular, the introduction was extented in order to present the motivations of our study and the related literature with more details.

Your journal has published the only study that addressed the question of gene-environment interactions for effects of Particulate Matter on birth weight (Suh et al., Reprod Toxicol, 2007). For this reason, we believe that our manuscript is particularly suited to Reproductive Toxicology.

Sincerely,

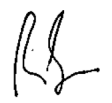

Rémy Slama, PhD

Corresponding author 


\author{
Rémy Slama ${ }^{1}$, Carolin Gräbsch ${ }^{2}$, Johanna Lepeule ${ }^{1}$, Valérie Siroux ${ }^{3}$, Josef Cyrys ${ }^{4,5}$, \\ Stefanie Sausenthaler ${ }^{4}$, Olf Herbarth ${ }^{3,6}$, Mario Bauer ${ }^{2}$, M. Borte ${ }^{7,8}$, H. Erich \\ Wichmann ${ }^{4}$, Joachim Heinrich ${ }^{4}$
}

\begin{abstract}
1: Inserm and Univ. J. Fourier Grenoble, Avenir Team "Environmental Epidemiology applied to Fecundity and Reproduction", U823, Institut Albert Bonniot, F-38042 Grenoble, France. 2: Helmholtz Centre for Environmental Research - UFZ, Department of environmental immunology, Permoserstr. 14, D-04318 Leipzig, Germany. 3: Inserm and Univ. J. Fourier Grenoble, U823, Team "Epidemiology of cancer and severe diseases", Institut Albert Bonniot, F-38042 Grenoble, France. 4: Helmholtz Zentrum München - German Research Center for Environmental Health, Institute of Epidemiology, D85763 Neuherberg, Germany. 5: Environment Science Center of the University Augsburg, D-86159 Augsburg, Germany. 6: University of Leipzig, Faculty of Medicine, Dept. Environmental Medicine and Hygiene, Leipzig, Germany. 7 University of Leipzig, Dept. of Paediatrics. 8: Municipal Hospital Saint Georg, Leipzig, Germany.
\end{abstract}

Address for correspondence:

Rémy Slama, PhD

Remy.slama@ujf-grenoble.fr

Team "Environmental Epidemiology applied to Fecundity and Human Reproduction" Inserm - Univ. J Fourier joint research center (U823) Institut Albert Bonniot BP 170 La Tronche F-38042 Grenoble CEDEX

France

Phone: +33 494769402

Fax: +33 494769414 
1

Abbreviations:

$\mathrm{Cl}$ : Confidence interval

CYP: cytochrome P 450

ETS: Environmental Tobacco Smoke

GST: glutathione S-transferase

$\mathrm{PM}_{2.5}$ : Fine Particulate Matter with an aerodynamical diameter below $2.5 \mu$

Running head:

Air pollution, genes and birthweight 


\section{ABSTRACT}

We aimed to describe if polymorphisms in xenobiotics-metabolizing genes modify the effect of maternal exposure to fine particulate matter $\left(\mathrm{PM}_{2.5}\right)$ on offspring birthweight.

Among newborns from LISA cohort, we tested if polymorphisms of GSTT1, GSTP1, GSTM1, and CYP2D6 genes modified the effect measure of $\mathrm{PM}_{2.5}$ on term birthweight. Subsequently, we tested if polymorphisms modified the effect of other exposure factors with similar pathways of action (active or passive smoking).

$\mathrm{PM}_{2.5}$ exposure above the median value (reference, below) was associated with birthweight changes by $76 \mathrm{~g}$ in the homozygous wild type genotype $(\mathrm{n}=161),-90 \mathrm{~g}$ in the heterozygous genotype $(\mathrm{n}=154)$ and $-168 \mathrm{~g}$ in children with GSTP1 ${ }^{*} 1 \mathrm{~B} /{ }^{*} 1 \mathrm{~B}$ mutant genotype $(\mathrm{n}=39$, interaction test, $\mathrm{p}=0.05)$. No effect measure modification with $\mathrm{PM}_{2.5}$ was detected for GSTT1, GSTM1 or CYP2D6 polymorphisms $(\mathrm{p} \geq 0.12)$. No effect measure modification with GSTP1 polymorphism was detected for active $(p=0.71)$ nor for passive smoking effects on birthweight $(p=0.13)$.

Key words: Air pollution; Birth Weight; Particulate Matter; Passive Smoking; Polymorphism, Genetic; Smoking. 


\section{INTRODUCTION}

Several studies reported associations between air pollution levels during pregnancy and measures of foetal size at birth [discussed e.g., by 1, 2, 3, 4]. A few of these studies attempted to identify factors that could entail variations in the estimated sensitivity of foetal size to air pollutants; sensitivity factors considered include sex of the offspring $[5,6,7]$, maternal parity [8], diet [9, 10] and genetic polymorphisms [11]. The latter were considered in only one study based on 199 births, in which two polymorphisms of CYP1A1 gene were assessed. No interaction tests have been reported, but birth weight changes associated with $\mathrm{PM}_{10}$ exposure above the $90^{\text {th }}$ percentile (compared to below the $90^{\text {th }}$ percentile) were not clearly in favor of an effect measure modification by any of the polymorphisms considered (see [11] and Table 1 of this paper). Therefore, there is currently very limited direct evidence for genetic polymorphisms modifying the effect measure of air pollutants on foetal growth in humans. Some genes implied in the metabolism of xenobiotics have been shown to modulate the action of drugs in the body $[12,13,14,15]$, and they appear worth being considered in the context of the study of air pollution effects.

The metabolism of xenobiotics can schematically be seen as a process in two phases; phase 1 usually corresponds to a functionalisation of xenobiotics, which makes them more electrophilic or nucleophilic, thus allowing a conjugation step, corresponding to the phase 2 of metabolism, which eventually leads to more hydrophilic compounds that can be more easily eliminated from the body than the parent xenobiotics. Examples of enzymes implied in phase 1 metabolism include the cytochrome P450 (CYP) superfamily. Within this superfamily, CYP2D6 belongs to the most polymorphic genes [16]. The glutathione transferases (GST) are a family of enzymes implied in phase 2 metabolism of xenobiotics such as polycyclic aromatic hydrocarbons (PAHs), which are present in atmospheric pollution [17]. The cytosolic GSTs include 7 classes of polymorphic enzymes, among which GSTM1, GSTT1 and GSTP1. GSTM1 and GSTT1 null polymorphisms correspond to a lack of expression of the corresponding enzyme [17]. Some of these genes have been considered in 
gene-environment interaction studies on human birth weight in relation to maternal active or passive smoking. In addition to the cytochrome P450 (CYP) superfamily and the glutathione transferases (GST) family, NQO1 $(\mathrm{NAD}(\mathrm{P}) \mathrm{H}$ : quinone oxidoreductase 1) and $E P H X 1$ (epoxide hydrolase 1) polymorphisms have also been considered (see Table 1 for a review). Hong et al. reported an increase in mean birth weight associated with exposure to passive smoking (ETS) in GSTT1 wild genotype and a decrease in mean birth weight associated with ETS exposure in GSTT1 null genotype [18]. In a case-control study, the estimated effect of ETS on mean birth weight also tended to be stronger in the offspring of mothers with GSTT1 null genotype than with GSTT1 wild genotype [19]. No clear statistical interaction have been described for polymorphisms of GSTM1 gene, and GSTP1 and CYP2D6 have so far very little been considered in this context.

Our aim here was to describe gene-environment interactions for air pollution exposure on birth weight, focusing on the polymorphisms of candidate genes implied in the metabolism of xenobiotics (GSTT1, GSTM1, GSTP1 and CYP2D6). Our study is based on a birth cohort in which we previously reported an increase in the frequency of birth weights below $3,000 \mathrm{~g}$ in association with $\mathrm{PM}_{2.5}$ ambient concentrations (particulate matter with an aerodynamical diameter below $2.5 \mathrm{~m}$, or fine $\mathrm{PM}$ ) and $\mathrm{PM}_{2.5}$ absorbance [20]. We used $\mathrm{PM}_{2.5}$ ambient concentrations (particulate matter with an aerodynamical diameter below $2.5 \mu$, or fine PM) as a marker of exposure to atmospheric pollutants. In cities from industrialized countries, $\mathrm{PM}_{2.5}$ are mainly derived from combustion processes such as road traffic, heating, biomass burning and specific industrial processes; additionally, a part of $\mathrm{PM}_{2.5}$ are derived from the conversion of gaseous precursors such as sulfur or nitrous oxides, ammonia or volatile organic compounds [21]. In the city of Munich, about $60 \%$ of the local emissions of the larger $\mathrm{PM}_{10}$ stem from (road and train) traffic [22], a proportion that is probably higher for $\mathrm{PM}_{2.5}$. $\mathrm{PM}_{2.5}$ are a complex mixture composed of air-suspended liquid and solid particles. From a chemical point of view, in urban sites, $\mathrm{PM}_{2.5}$ are mainly composed of secondary aerosol (ammonium nitrate and ammonium sulfate), organic matter (including many types of volatile, 
semivolatile and non-volatile compounds, such as PAHs and benzene) and elemental carbon [23].

In a first step, we studied modifications of the effect measure of $\mathrm{PM}_{2.5}$ exposure on birth weight by genetic polymorphisms. Human exposure to combustion-related air pollution occurs through the same pathway (inhalation) as exposure to tobacco smoke; these two mixtures also share similarities in terms of granulometry of their particulate component [24, $25]$ and also in terms of chemical composition. Indeed, tobacco smoke particulate matter has an aerodynamic diameter typically in the $50-800 \mathrm{~nm}$ range [25], which covers the $10-100 \mathrm{~nm}$ range, corresponding to fresh traffic-related PM [24]. Many families of combustions byproducts such as volatile organic compounds (e.g., benzene) or polycyclic aromatic hydrocarbons are present in both mixtures. A notable difference is nicotine, which is present in tobacco smoke but not in traffic-related air pollution. In terms of effects on reproductive function, maternal exposure to each of these mixtures has been associated with decrements in term birth weight in humans $[3,26]$. Therefore, we hypothesized that, if causal coactions (biological interaction) existed between $\mathrm{PM}_{2.5}$ and a specific genetic polymorphism, it may also be present for environmental tobacco smoke (ETS) exposure or active smoking. Accordingly, in a second step, we focused on the polymorphism(s) detected in the analysis implying $\mathrm{PM}_{2.5}$ exposure, and studied if this (these) polymorphism(s) also modified the effect measure of active or passive smoking on birth weight. The existence of a coherent pattern of interaction for all three environmental exposures studied was then considered to discuss the plausibility of any effect measure modification observed with atmospheric pollutants. 


\section{MATERIALS AND METHODS}

\subsection{Study population}

In the LISA (Influences of Lifestyle Related Factors on the Human Immune System and Development of Allergies in Children) birth cohort, women were included after delivery in maternities from obstetrical clinics in the cities of Munich, Leipzig, Wesel and Bad Honef, Germany, between November 1997 and January 1999. Exclusion criteria for the mother were among others immune-related diseases (including diabetes) and being on long-term medication [27]; parents had to be born in Germany and to have the German nationality, which strongly limited the ethnical diversity of the study population. Exclusion criteria for the child were: a birth weight below $2500 \mathrm{~g}$, a gestational duration below 37 completed weeks, congenital malformation, symptomatic neonatal infection, antibiotic medication and hospitalization or intensive medical care during neonatal period [27]. We further excluded twin births.

The study was approved by the ethics commissions of the Landesaerztekammer Bavaria and of the University of Leipzig and was carried out in accordance with the international guidelines for the protection of human subjects. Parents of all subjects gave written informed consent.

Gestational duration and birthweight were collected from the records filled in at birth by the midwife.

\subsection{Exposure to cigarette smoke}

Women answered a questionnaire shortly after delivery, allowing to collect information on active smoking, ETS, current address, changes of address during pregnancy, height and educational level. Information on active and passive smoking was obtained for each trimester of pregnancy. For active smoking, we considered only active smoking during the third trimester, which was more strongly associated with birth weight in analyses not taking into 
account genetic polymorphisms than exposure during either the first, the second or any of the three trimesters. Similarly, we considered as exposed to ETS women who declared to have been exposed to passive smoking during the third trimester of pregnancy.

\subsection{Exposure to $\mathrm{PM}_{2.5}$}

Exposure to $\mathrm{PM}_{2.5}$ was estimated using a previously defined temporally-adjusted land use regression model. The model was based on a measurement campaign of $\mathrm{PM}_{2.5}$ in 40 locations across Munich inner city and was initially developed to yield an estimate of a yearly average of air pollution levels $[28,29,30]$. It was thereafter expanded to incorporate a temporal component allowing to estimate an average of exposure during the whole pregnancy [20]. No similar exposure model has been developed for newborns from the other recruitment centers. All analyses implying air pollution levels were conducted excluding women who changed home during pregnancy, as we did not know their previous home address.

\subsection{Genotyping}

Blood samples were taken from the child at 6 years of age; because of this and because not all parents accepted to give their written consent for genetic analyses, these were only performed on a subgroup of the original birth cohort. Genotyped and non-genotyped cohort members have been compared (see online supplement). DNA was extracted from a thawed whole blood sample by use of a QIAamp Blood Kit (Qiagen) according to the "blood and body fluid protocol" recommended by the manufacturer. We used $600 \mu \mathrm{l}$ of the blood sample for DNA extraction. The 4 genes considered are implied in the metabolism of xenobiotics. GSTT1 and GSTM1 null genotypes correspond to a loss of glutathione transferase activity [31]. GSTP1 represents the main glutathione transferase isoenzyme in the lung. The non- 
synonymous GSTP1 polymorphism (rs1695, 313A>G, lle105Val) has been associated with

reduced enzyme activity and anticancer drug resistance and toxicity $[12,13]$. CYP2D6 is highly polymorphic, with polymorphism 1846G>A (rs 1800716) causing a splicing defect that results in a non-functional protein [32,33]. This variant is responsible for the majority of the reduced enzyme activity found in Caucasian populations [34]. Genotyping of GSTM1, GSTT1 and GSTP1 was performed following Bauer et al. [35]: we used a multiplex PCR approach. Briefly, $10 \mathrm{ng}$ genomic DNA was amplified in a $20 \mu \mathrm{l}$ reaction mixture containing $10 \mathrm{pmol}$ of each of the following primers: GSTM1_for 5'-GTGGAGACAGAAGAAGAGAAGA-3', GSTM1_rev 5'AGAGGCCAGAGCTGA TGAAGG-3', GSTT1_for 5'ACCCTGGCAGAGTTGGATGTGACC-3', GSTT1_rev 5'GTGGAAGACAGGGTGGGGATGGT-3'. As an internal positive control, the RON gene was co-amplified with the primers RON_for 5'-CTAGTGGGGAGGTGGAGCAGATA-3' and RON_rev 5'-AAGCAGGTCCAGCCCAAGAACTAA-3'. PCR was performed at $94^{\circ} \mathrm{C}$ for $5 \mathrm{~min}$, then 38 cycles at $94^{\circ} \mathrm{C}$ for $30 \mathrm{~s}$, at $60^{\circ} \mathrm{C}$ for $30 \mathrm{~s}$, at $72^{\circ} \mathrm{C}$ for $1 \mathrm{~min}$ and extension at $72^{\circ} \mathrm{C}$ for $10 \mathrm{~min}$. The PCR mixture contained $1.25 \mathrm{mM} \mathrm{MgCl}_{2}, 200 \mu \mathrm{M}$ each dNTPS, $10 \mathrm{pmol}$ of each primer and $1 \mathrm{U}$ BIOTAQ DNA polymerase (Bioline, Luckenwalde, Germany). We used PCR mixture without DNA as a negative control to exclude false-positive data. The multiplex PCR products were then electrophoretically analysed on a $2 \%$ ethidium bromide-stained agarose gel (QA-Agarose, Qbiogene, Heidelberg, Germany). The presence or absence of GSTM1 and GSTT1 genes was detected by the presence or absence of a 688-bp (corresponding to GSTT1) and a 378-bp (corresponding to GSTM1) PCR band. GSTP1 lle $105 \mathrm{Val}$ polymorphism was detected by means of restriction fragment length polymorphism approach. Genomic DNA was amplified by PCR with the GSTP1_14_for 5'CTGCCCCCGGAGCCCTTTTGTTTA3' and GSTP1_15_rev 5' CTCGCCCCCATG ACCCGTTACTTG-3' primer pair giving a 655 -bp PCR product. The PCR product was consecutively restricted by BsmAl endonuclease (Fermentas, St. Leon-Rot, Germany) for 2 hours at $37^{\circ} \mathrm{C}$. The reaction mixture was analysed by agarose gel electrophoresis. A 3-band and 4-band restriction pattern was identified as 105 Ile and Val, respectively. 
For CYP2D6, we used the approach described by Hersberger et al. [36]. As a quality control

procedure, we repeated the genotyping of a random sample of $3 \%$ of our study population, which showed a $100 \%$ agreement with the original genotyping. Genotyping was performed at Helmholtz Center for Environmental Research (UFZ) Leipzig. We performed a HardyWeinberg equilibrium test for GSTP1 and CYP2D6 polymorphisms; the test could not be performed for GSTT1 and GSTM1 polymorphisms because the genotyping approach used did not differentiate the homozygotic wild type variant and the heterozygotic wild typemissing variant.

\subsection{A priori hypotheses}

Based on analogies with previous studies on smoking or air pollutants and birth weight (Table 1) or respiratory health, our a priori hypotheses were that the deleterious effect of exposure would tend to be greater for the null genotype of GSTM1 [18, 37, 38] and GSTT1 $[18,19,39]$, compared to the present genotype. We made no a priori hypotheses for the polymorphisms of GSTP1 and CYP2D 6 because the literature on atmospheric pollutants was more scant for these genes.

\subsection{Regression models}

Statistical models were implemented using STATA software (version 10, College Station, TX). A statistical interaction cannot generally be considered to correspond to a biological interaction (or causal coaction); however, sufficient conditions for a statistical interaction to correspond to causal coaction have been identified in the case of a departure from additivity of the estimated effects of exposures [40, p.81-82, 41]. Since linear regression allows testing for a departure from additivity and also since the sample size with available $\mathrm{PM}_{2.5}$ data was too limited to dichotomize birthweight (below vs. above $3000 \mathrm{~g}$ ), we analysed birthweight as a continuous outcome. A different regression model was estimated for each pair of 
environmental factor and genetic polymorphism. Interaction tests corresponded to the test of significance of the product terms between exposure and genotype in the adjusted regression models.

The effect measure modification with ETS was tested only among non-smoking mothers to limit the potential for residual confounding by active smoking. When we considered the effect of active smoking or ETS, we adjusted for maternal parity, education, height, pre-pregnancy weight and center. When we considered the effect of $\mathrm{PM}_{2.5}$, we further adjusted for active smoking, as in our previous study [20].

\subsection{Sensitivity analysis}

We conducted an analysis aiming at quantifying the direction and amplitude of any bias resulting from the fact that birth weights below $2500 \mathrm{~g}$ had not been recruited. The approach was slightly modified from a bootstrap approach previously implemented in our study on the same population [20]. This bootstrap approach consisted in adding to the study population an extra population drawn at random from the newborns with a weight between 2500 and 2750 $\mathrm{g}$, but assuming that their weight was $2375 \mathrm{~g}$ (the median birth weight among singleton term births weighing less than $2500 \mathrm{~g}$ in another cohort [6] in which newborns with a weight below $2500 \mathrm{~g}$ had been recruited). We then drew a bootstrap sample from this augmented population sample including $2.2 \%$ of birthweights below $2500 \mathrm{~g}$, and estimated the joint effect of the genetic polymorphisms and the considered environmental factor in this sample using the linear regression model presented above. The bootstrap step has been replicated 1,000 times and the parameters associated with environmental factors have been averaged over these replications. The approach has been repeated excluding the offspring of mothers who smoked for the study of effect measure modifications with ETS. 


\section{RESULTS}

\subsection{Study population}

The LISA cohort included 3038 singleton children, out of which 992 had a blood sample taken that allowed genotyping (Figure 1). Children with genotypic and smoking information had a mean birth weight of $3,495 \mathrm{~g}(\mathrm{SD}, 435 \mathrm{~g})$, similar to that of the remaining 2046 children (mean, $3481 \mathrm{~g}, \mathrm{SD}, 441 \mathrm{~g}, \mathrm{p}=0.4$, supplementary material, Table S1). GSTT1 polymorphism tended to be associated with active smoking status, and GSTM1 polymorphism with ETS (Table 2); these associations became stronger ( $p=0.03$ and $p=0.05$, respectively) after exclusion of observations with a birthweight below 3000 g. CYP2D6 polymorphism was not in Hardy-Weinberg equilibrium $(p<0.01)$, while there was no evidence of a deviation from equilibrium for GSTP1 ( $\mathrm{p}=0.89)$.

3.2 Fine particulate matter exposure and birth weight by genetic polymorphisms

A PM 2.5 level above the median $\left(14.4 \mu \mathrm{g} / \mathrm{m}^{3}\right)$ was associated with a change by $-22 \mathrm{~g}$ in mean birth weight (95\% Cl: $-99,55 \mathrm{~g}, 386$ observations), regardless of genetic polymorphisms (Table 3). There was some evidence for an effect measure modification of $\mathrm{PM}_{2.5}$ by the GSTP1 polymorphism: a $\mathrm{PM}_{2.5}$ level above the median corresponded to an adjusted change in mean birth weight by $76 \mathrm{~g}(\mathrm{p}=0.18)$ in the homozygous wild type genotype, by $-90 \mathrm{~g}$ in the heterozygous ${ }^{*} 1 \mathrm{~B} /$ wild type genotype $(\mathrm{p}=0.12)$ and by $-168 \mathrm{~g}$ in the homozygous mutant $\left({ }^{*} 1 B\right)$ genotype $(p=0.15$; interaction test, $p=0.05$; Table 4 and supplementary material, Figure S1A). Repeating the analysis among non-smoking pregnant women did not weaken the strength of the statistical interaction between $\mathrm{PM}_{2.5}$ exposure and GSTP1 polymorphism $(p=0.02)$. No clear effect measure modification with $\mathrm{PM}_{2.5}$ was detected for the other genetic polymorphisms ( $p \geq 0.12$, Table 4). 


\subsection{Active smoking and birth weight by genetic polymorphisms}

Maternal smoking during pregnancy was associated with an adjusted change by $-156 \mathrm{~g}$ in birth weight, non-smoking women being taken as a reference (95\% Cl: -250; -61 g; Table 3). The effect of smoking corresponded to a change in mean birthweight by $-173 \mathrm{~g}$ for the GSTP1 homozygous wild type genotype, by $-122 \mathrm{~g}$ for the heterozygous *1B/wild type GSTP1 genotype and by -248 $\mathrm{g}$ in the homozygous mutant $\left({ }^{*} 1 B\right)$ genotype (interaction test, $\mathrm{p}=0.71$, Table 5). Results changed little after restriction to the population with available $\mathrm{PM}_{2.5}$ exposure (interaction test, $\mathrm{p}=0.54$, not detailed). There was no strong evidence of a departure from additivity for combined effects of polymorphism and active smoking for the three other considered polymorphisms either (interaction tests, $p \geq 0.19$, Table 5).

\subsection{Passive smoking and birth weight by genetic polymorphisms}

ETS was associated with a change by $-28 \mathrm{~g}$ in mean birth weight in the genotyped population $(95 \% \mathrm{Cl},-113,57 \mathrm{~g}$; Table 3). It was associated with a change by $-31 \mathrm{~g}$ in the GSTP1 homozygous wild type phenotype, by $33 \mathrm{~g}$ in the heterozygous genotype and by $-241 \mathrm{~g}$ in the homozygous mutant $\left({ }^{*} 1 B\right)$ genotype (interaction test, $\mathrm{p}=0.13$ ). After restriction to the subjects with available $\mathrm{PM}_{2.5}$ exposure ( $\left.\mathrm{n}=311\right)$, ETS was associated with an adjusted birth weight change by $-199 \mathrm{~g}$ in the GSTP1 homozygous wild type genotype (95\% Cl: -426, $28 \mathrm{~g}, 10$ exposed subjects), by $75 \mathrm{~g}$ in the heterozygous genotype (95\% Cl: $-147,297 \mathrm{~g}, 11$ exposed subjects) and by -388 $\mathrm{g}$ in the homozygous mutant genotype (95\% Cl: $-806,31 \mathrm{~g} ; 3$ exposed subjects; interaction test, $\mathrm{p}=0.08$ ).

For comparison purposes, we summarize here the results of Tables 4 to 6 in terms of amplitude of association with birth weight: for $\mathrm{PM}_{2.5}$, the strongest estimated effects of exposure were seen in the homozygous mutant $\left({ }^{*} 1 B /{ }^{*} 1 B\right)$ genotype of GSTP1 $\left(\beta_{\mathrm{GSTP} 1}=-168\right.$ 
g) and homozygous mutant ${ }^{*} 4 /{ }^{*} 4$ genotype of CYP2D6 $\left(\beta_{\mathrm{CYP}}=-311 \mathrm{~g}\right)$; this was also the case for ETS ( $\beta_{\mathrm{GSTP} 1}=-241 \mathrm{~g}, \beta_{\mathrm{CYP}}=-278 \mathrm{~g}$ ). For active smoking, the strongest estimated effects on birth weight were detected for GSTP1 homozygous mutant $\left({ }^{*} 1 B /{ }^{*} 1 B\right)$ genotype $\left(\beta_{\mathrm{GSTP} 1}=-\right.$ $248 \mathrm{~g})$ and for CYP2D6 homozygous wild type genotype ( $\left.\beta_{\mathrm{CYP}}=-195 \mathrm{~g}\right)$.

\subsection{Sensitivity analysis}

The gene-environment patterns corrected for the exclusion of birth weights below $2500 \mathrm{~g}$ (Figure $2 \mathrm{~B}$ ) remained qualitatively similar to those not corrected for the exclusion of birth weights below $2500 \mathrm{~g}$ (Figure 2A). 


\section{DISCUSSION}

In this birth cohort, Ile105Val polymorphism in GSTP1 gene tended to modify the effect measure of $\mathrm{PM}_{2.5}$ levels around the maternal home address averaged during pregnancy on birth weight. There was no strong evidence that this polymorphism modified the effect measure of active or passive smoking on birth weight.

\section{1 $\mathrm{PM}_{2.5}$ and birth weight}

A study in Korea among 199 newborns reported associations between $\mathrm{PM}_{10}$ exposure level (as estimated from the permanent monitoring stations network) during the first trimester of pregnancy and birth weight, by genetic polymorphisms of the CYP1A1 gene [11]. The results (summarized in our Table 1) did not mention interaction tests, but the point estimates did not speak in favour of a clear effect measure modification with $\mathrm{PM}_{10}$ exposure, at least for $\mathrm{Ncol}$ polymorphism of CYP1A1. We are not aware of a study that considered the same genetic polymorphisms as those taken into account in our study. $\mathrm{PM}_{2.5}$ effects tended to be stronger in the GSTP1 lle105Val mutant genotype than in the homozygous wild type. We could control for a variety of potential confounders such as maternal size, pre-pregnancy weight, socio-economic status, active and passive smoking. As an alternative way to control for active smoking, we repeated the analysis among non-smoking pregnant, and the statistical interaction between $\mathrm{PM}_{2.5}$ exposure and GSTP1 was still present $(\mathrm{p}=0.02)$, confirming that this statistical interaction was unlikely to be explained by factors known to influence birth weight. GSTP1 codes for a phase-Il glutathione transferase enzyme, which has been recognized to detoxify chemicals [31], and Ile105Val genotype has been associated with reduced enzyme activity [13]. Therefore, assuming that glutathione-conjugated pollutants are less strongly active than unconjugated pollutants, there is some biological plausibility to the decrease in birth weight associated with $\mathrm{PM}_{2.5}$ being strongest for this mutant genotype. The 
fact that $\mathrm{PM}_{2.5}$ exposure tended to be associated with an increased birth weight $(p=0.18)$ in the wild type genotype was unexpected, and might be due to random fluctuation.

We genotyped the newborns and not their mothers. GSTP1 has been shown to be active in fetus [42]. Some correlation between maternal and foetal heterozygosity can generally be expected [43], so that heterozygosity of the offspring may be a proxy of maternal heterozygosity. In the absence of genotyping of the mothers, and even if the statistical interaction detected corresponded to causal coactions, one should therefore refrain to interpret this interaction as bringing evidence for the offspring genes rather than the maternal ones being implied in the pathway between fine particulate matter exposure and foetal growth. There was no statistical interaction between $\mathrm{PM}_{2.5}$ exposure and the three other genes tested; results concerning CYP2D6 should be interpreted with caution because of a possible deviation from Hardy-Weinberg equilibrium.

\subsection{Tobacco smoke and birth weight}

The estimated effect of exposure tended to be strongest in the mutant homozygous genotypes of CYP2D6 and GSTP1 for both ETS and $\mathrm{PM}_{2.5}$ exposure; however, there was no clear evidence of an effect measure modification between ETS and GSTP1 $(p=0.13)$. Since the approach based on the significance level being lower than a given threshold corresponded to our a priori choice, and since this approach might more easily be generalized to studies implying a larger number of polymorphisms than ours, we did not further consider the more qualitative similarity between ETS and $\mathrm{PM}_{2.5}$ in terms of the genotypes for which the apparent effect of exposure was strongest. Additionally, the effect of active smoking on birth weight did not clearly differ between the GSTP1 mutant and wild type genotypes. Therefore, we considered that there was no coherent interaction pattern with genetic polymorphisms for the three exposure variables considered. 
Although quite imprecise, our results concerning GSTM1 were qualitatively in agreement with previous reports in which mothers had been genotyped, in favour of ETS being associated with greater decrements in mean birth weight in GSTM1 null genotype, compared to GSTM1 present genotype [18, 19].

\subsection{Assessment of environmental exposures}

The strengths of the approach we used to assess exposure were that we restricted the study to women who had not changed address during pregnancy, that our land-use regression exposure model was based on a measurement campaign in 40 sites of Munich city [20, 30], which allows a finer spatial resolution than approaches relying only on the network of air quality monitoring stations [20]. Limitations were that exposures away from the home address were not taken into account, and that estimated outdoor $\mathrm{PM}_{2.5}$ levels were taken as a surrogate for personal exposure at the home address. A longitudinal exposure assessment study in Europe reported median coefficients of correlation between individual exposure and outdoor levels assessed in the vicinity of the home ranging from 0.7 to 0.8 for $\mathrm{PM}_{2.5}$ [44], but a meta-analysis based on US studies reported lower correlations [45]. We estimated ETS exposure from a retrospective questionnaire filled by the mother at birth. This approach is generally prone to exposure misclassification [46] but few simple alternatives exist since cotinine, which is generally considered a relevant biomarker of ETS exposure in the general population, has a half-life of only about 9 hours in pregnant women [47].

\subsection{Selection of study sample}

The LISA birth cohort was primarily designed to study the impact of environmental exposures during early childhood on the occurrence of adverse health outcomes in childhood and adolescence. Preterm birth and low birthweight can be associated with adverse health 
outcomes in childhood, which is the reason why premature and low birthweight $(<2500 \mathrm{~g})$ newborns had not been recruited. We conducted a sensitivity analysis assuming that low birthweight babies corresponded to $2.2 \%$ of singleton live term births, a figure based on the Eden mother-child cohort [6,48], and close to the figure of $1.9 \%$ observed in Germany for the year 2004 [49]. This sensitivity analysis indicated that this exclusion is unlikely to have strongly affected our results. Population stratification bias is another source of error in genetic studies. This term is used to denote confounding by an unmeasured factor (such as ethnicity) associated with the health outcome and the genetic polymorphism under study [50]. If not controlled for, this unmeasured factor may entail a bias in the estimation of the main genetic effect on the health outcome, or of gene-gene or gene-environment interactions [51]. In our cohort, both parents had to be born in Germany and to have the German nationality in order for their child to be eligible in the cohort which, given the rather stringent laws regarding citizenship at the end of the 1990s, strongly limited the proportion of parents whose family immigrated from outside Europe in the recent generations. Therefore, our population was rather homogeneous from an ethnic point of view. This makes a population stratification bias due to ethnic factors unlikely.

\subsection{Statistical approach}

Under some hypotheses, and at least in the case of binary outcome measures, departure from additivity can allow to infer the presence of causal coactions between the two explanatory variables considered [40, p.81-82, 41]. For this reason, and also because of a more limited sample size, we a priori decided to analyze birth weight using a linear regression model, and not using a multiplicative model with a dichotomized outcome as in our previous study on air pollution effects on birth weight relying on the same cohort [20]. In addition to lack of unmeasured confounding and proper model specification, sufficient hypotheses allowing to infer the presence of causal coactions from departure from additivity 
include that neither of the two explanatory factors considered can act as a preventive factor

[40, p.81-82, 41]; these hypotheses have been derived in the context of binary (and not continous) outcomes. In our study, GSTP1 mutant genotype tended to be associated with a decrease in birth weight, but this is not enough to exclude a positive effect of this genotype in specific subgroups of the population. Therefore, sufficient conditions to make inferences on causal coaction of $\mathrm{PM}_{2.5}$ exposure and GSTP1 polymorphisms based on the statistical interaction are not established in our study.

\section{CONCLUSION}

In a context where very few cohorts simultaneously offer an accurate assessment of exposure to atmospheric pollutants during pregnancy and information on genotype, alternatives to straightforward replication of gene-environment studies are worth being investigated. Our approach consisted in looking for similarities in interaction patterns between various environmental pollutants. It assumed that, because of closeness in chemical nature and pathway of exposure, tobacco smoke and atmospheric pollutants would share common metabolic pathways, which would translate into similar patterns of statistical interaction with xenobiotics-metabolizing genes. Tobacco smoke and traffic-related air pollutants indeed have similarities in terms of chemical nature, with many families of combustions by-products such as volatile organic compounds (e.g., benzene) or polycyclic aromatic hydrocarbons being present in both mixtures. A notable difference is nicotine, which is present in tobacco smoke but not in traffic-related air pollution. In terms of PM, trafficrelated fresh pollutants typically have an aerodynamical diameter in the $10-100 \mathrm{~nm}$ range [24], while PM from tobacco smoke usually is in the $50-800 \mathrm{~nm}$ range [25]. The fact that GSTP1 polymorphism modified the effect measure of $\mathrm{PM}_{2.5}$ on birth weight but not that of active or passive smoking may be due to this statistical interaction not reflecting a biological interaction. For this reason, we warrant against interpreting this statistical interaction as an 
evidence of combustion-related atmospheric pollutants acting on foetal growth through a pathway implying glutathione transferase enzymes. 


\section{ACKNOWLEDGEMENTS}

R.S. benefited from a position of invited researcher funded by Helmholtz Centre Munich and Inserm during part of the project. The team "Environmental Epidemiology applied to Fertility and Reproduction" is funded by an Avenir Grant (2007) from Inserm.

\section{CONFLICT OF INTEREST STATEMENT}

Authors declare that they have no conflict of interest. 


\section{REFERENCES}

1. Glinianaia SV, Rankin J, Bell R, Pless-Mulloli T, Howel D. Particulate air pollution and fetal health: a systematic review of the epidemiologic evidence. Epidemiology 2004;15:36-45.

2. Lacasana M, Esplugues A, Ballester F. Exposure to ambient air pollution and prenatal and early childhood health effects. Eur J Epidemiol 2005;20:183-99.

3. Slama R, Darrow LA, Parker JD, Woodruff TJ, Strickland M, Nieuwenhuijsen M, et al. Atmospheric Pollution and Human Reproduction: Report of the Munich International Workshop. Environ Health Perspect 2008;116:791-8.

4. Sram RJ, Binkova B, Dejmek J, Bobak M. Ambient air pollution and pregnancy outcomes: a review of the literature. Environ Health Perspect 2005;113:375-82.

5. Ghosh R, Rankin J, Pless-Mulloli T, Glinianaia S. Does the effect of air pollution on pregnancy outcomes differ by gender? A systematic review. Environ Res 2007; 105:400-8.

6. Slama R, Thiebaugeorges O, Goua V, Aussel L, Sacco P, Bohet A, et al. Maternal personal exposure to airborne benzene and intrauterine growth. Environ Health Perspect 2009;117:1313-21.

7. Jedrychowski W, Perera F, Mrozek-Budzyn D, Mroz E, Flak E, Spengler JD, et al. Gender differences in fetal growth of newborns exposed prenatally to airborne fine particulate matter. Environ Res 2009.

8. Ritz B, Yu F. The effect of ambient carbon monoxide on low birth weight among children born in southern California between 1989 and 1993. Environ Health Perspect 1999;107:17-25.

9. Jedrychowski W, Masters E, Choi H, Sochacka E, Flak E, Mroz E, et al. Pre-pregnancy dietary vitamin A intake may alleviate the adverse birth outcomes associated with prenatal pollutant exposure: epidemiologic cohort study in Poland. Int J Occup Environ Health 2007;13:175-80.

10. Kannan S, Misra DP, Dvonch JT, Krishnakumar A. Exposures to airborne particulate matter and adverse perinatal outcomes: a biologically plausible mechanistic framework for exploring potential effect modification by nutrition. Environ Health Perspect 2006;114:1636-42.

11. Suh YJ, Kim BM, Park BH, Park H, Kim YJ, Kim H, et al. Cytochrome P450IA1 polymorphisms along with $\mathrm{PM}(10)$ exposure contribute to the risk of birth weight reduction. Reprod Toxicol 2007.

12. Lecomte T, Landi B, Beaune P, Laurent-Puig P, Loriot MA. Glutathione S-transferase P1 polymorphism (lle105Val) predicts cumulative neuropathy in patients receiving oxaliplatin-based chemotherapy. Clin Cancer Res 2006;12:3050-6.

13. Watson MA, Stewart RK, Smith GB, Massey TE, Bell DA. Human glutathione Stransferase P1 polymorphisms: relationship to lung tissue enzyme activity and population frequency distribution. Carcinogenesis 1998;19:275-80.

14. Mcllwain CC, Townsend DM, Tew KD. Glutathione S-transferase polymorphisms: cancer incidence and therapy. Oncogene 2006;25:1639-48.

15. Zhou SF, Liu JP, Chowbay B. Polymorphism of human cytochrome P450 enzymes and its clinical impact. Drug Metab Rev 2009;41:89-295.

16. Rodriguez-Antona C, Ingelman-Sundberg M. Cytochrome P450 pharmacogenetics and cancer. Oncogene 2006;25:1679-91.

17. Hayes JD, Flanagan JU, Jowsey IR. Glutathione transferases. Annu Rev Pharmacol Toxicol 2005;45:51-88.

18. Hong YC, Lee KH, Son BK, Ha EH, Moon HS, Ha M. Effects of the GSTM1 and GSTT1 polymorphisms on the relationship between maternal exposure to environmental tobacco smoke and neonatal birth weight. J Occup Environ Med 2003;45:492-8.

19. Wang X, Zuckerman B, Pearson C, Kaufman G, Chen C, Wang G, et al. Maternal cigarette smoking, metabolic gene polymorphism, and infant birth weight. JAMA 2002;287:195-202. 
20. Slama R, Morgenstern V, Cyrys J, Zutavern A, Herbarth O, Wichmann HE, et al. TrafficRelated Atmospheric Pollutants Levels during Pregnancy and Offspring's Term Birth Weight: A Study Relying on a Land-Use Regression Exposure Model. Environ Health Perspect 2007;115:1283-92.

21. Pope CA, 3rd, Dockery DW. Health effects of fine particulate air pollution: lines that connect. J Air Waste Manag Assoc 2006;56:709-42.

22. Regierung von Oberbayern. Luftreinhalteplan fu $\square \mathrm{r}$ die Stadt $\mathrm{Mu} \square$ nchen. Munich (Germany), 2004, (Department (Government Body no. Section). http://www.muenchen.de/cms/prod1/mde/ de/rubriken/Rathaus/70 rgu/04 vorsorge schutz/luft/pdf/luftreinhalteplan.pdf

23. Krzyzanowski M, Kuna-Dibbert B, Schneider J eds. Health Effects of Transport-related Air Pollution. Copenhagen: World Health Organization, Regional Office for Europe, 2005.

24. Schauer JJ, Kleeman MJ, Cass GR, Simoneit BR. Measurement of emissions from air pollution sources. 5. C1-C32 organic compounds from gasoline-powered motor vehicles. Environ Sci Technol 2002;36:1169-80.

25. Kleeman MJ, Schauer JJ, Cass GR. Size and composition distribution of fine particulate matter emitted from wood burning, meat charbroiling, and cigarettes. Environ Sci Technol 1999;33:3516-23.

26. Lindley AA, Becker S, Gray $\mathrm{RH}$, Herman AA. Effect of continuing or stopping smoking during pregnancy on infant birth weight, crown-heel length, head circumference, ponderal index, and brain:body weight ratio. American Journal of Epidemiology 2000;152:219-25.

27. Gehring U, Cyrys J, Sedlmeir G, Brunekreef B, Bellander T, Fischer P, et al. Trafficrelated air pollution and respiratory health during the first 2 yrs of life. Eur Respir $\mathrm{J}$ 2002;19:690-8.

28. Brauer M, Hoek G, van Vliet P, Meliefste K, Fischer P, Gehring U, et al. Estimating longterm average particulate air pollution concentrations: application of traffic indicators and geographic information systems. Epidemiology 2003;14:228-39.

29. Cyrys J, Heinrich J, Hoek G, Meliefste K, Lewne M, Gehring U, et al. Comparison between different traffic-related particle indicators: elemental carbon (EC), PM2.5 mass, and absorbance. J Expo Anal Environ Epidemiol 2003;13:134-43.

30. Morgenstern V, Zutavern A, Cyrys J, Brockow I, Gehring U, Koletzko S, et al. Respiratory health and individual estimated exposure to traffic-related air pollutants in a cohort of young children. Occup Environ Med 2007;64:8-16.

31. Hayes JD, Strange RC. Glutathione S-transferase polymorphisms and their biological consequences. Pharmacology 2000;61:154-66.

32. Kagimoto M, Heim M, Kagimoto K, Zeugin T, Meyer UA. Multiple mutations of the human cytochrome P450IID6 gene (CYP2D6) in poor metabolizers of debrisoquine. Study of the functional significance of individual mutations by expression of chimeric genes. J Biol Chem 1990;265:17209-14.

33. Gough AC, Miles JS, Spurr NK, Moss JE, Gaedigk A, Eichelbaum M, et al. Identification of the primary gene defect at the cytochrome P450 CYP2D locus. Nature 1990;347:773-6.

34. Marez D, Legrand M, Sabbagh N, Guidice JM, Spire C, Lafitte JJ, et al. Polymorphism of the cytochrome P450 CYP2D6 gene in a European population: characterization of 48 mutations and 53 alleles, their frequencies and evolution. Pharmacogenetics 1997;7:193-202.

35. Bauer M, Herbarth O, Aust G, Hengstler JG, Dotzauer A, Graebsch C, et al. Expression patterns and novel splicing variants of glutathione-S-transferase isoenzymes of human lung and hepatocyte cell lines. Cell Tissue Res 2006;324:423-32.

36. Hersberger M, Marti-Jaun J, Rentsch K, Hanseler E. Rapid detection of the CYP2D6*3, CYP2D6*4, and CYP2D6*6 alleles by tetra-primer PCR and of the CYP2D6*5 allele by multiplex long PCR. Clin Chem 2000;46:1072-7. 
37. Romieu I, Sienra-Monge JJ, Ramirez-Aguilar M, Moreno-Macias H, Reyes-Ruiz NI, Estela del Rio-Navarro B, et al. Genetic polymorphism of GSTM1 and antioxidant supplementation influence lung function in relation to ozone exposure in asthmatic children in Mexico City. Thorax 2004;59:8-10.

38. Gilliland FD, Li Y-F, Dubeau L, Berhane K, Avol E, McConnell R, et al. Effects of Glutathione S-Transferase M1, Maternal Smoking during Pregnancy, and Environmental Tobacco Smoke on Asthma and Wheezing in Children. Am J Respir Crit Care Med 2002;166:457-63.

39. Infante-Rivard C, Weinberg CR, Guiguet M. Xenobiotic-metabolizing genes and smallfor-gestational-age births: interaction with maternal smoking. Epidemiology 2006;17:38-46.

40. Rothman KJ, Greenland S, Lash TL. Modern epidemiology. Philadelphia, PA: Lippincott Williams \& Wilkins, 2008.

41. VanderWeele TJ, Robins JM. The identification of synergism in the sufficientcomponent-cause framework. Epidemiology 2007;18:329-39.

42. Raijmakers MTM, Steegers EAP, Peters WHM. Glutathione S-transferases and thiol concentrations in embryonic and early fetal tissues. Hum Reprod 2001;16:2445-50.

43. Mitton JB, Schuster WS, Cothran EG, De Fries JC. Correlation between the individual heterozygosity of parents and their offspring. Heredity 1993;71 (Pt 1):59-63.

44. Brunekreef B, Janssen NA, de Hartog JJ, Oldenwening M, Meliefste K, Hoek G, et al. Personal, indoor, and outdoor exposures to PM2.5 and its components for groups of cardiovascular patients in Amsterdam and Helsinki. Res Rep Health Eff Inst 2005:170; discussion 1-9.

45. Avery CL, Mills KT, williams R, McGraw KA, Poole C, Smith RL, et al. Estimating Error in Using Residential Outdoor PM2.5 Concentrations as Proxies for Personal Exposures: a Meta-Analysis. Environ Health Perspect (in press).

46. Proctor CJ, Warren ND, Bevan MAJ, Baker-Rogers J. A comparison of methods of assessing exposure to environmental tobacco smoke in non-smoking British women. Environment International 1991;17:287-97.

47. Dempsey D, Jacob P, 3rd, Benowitz NL. Accelerated metabolism of nicotine and cotinine in pregnant smokers. J Pharmacol Exp Ther 2002;301:594-8.

48. Drouillet $P$, Kaminski $M$, De Lauzon-Guillain $B$, Forhan $A$, Goua $V$, Thiébaugeorges $O$, et al. Association between maternal fish and shells consumption before pregnancy and fetal growth: evidence for an association in overweight women. The "EDEN motherchild" cohort (study of pre and early postnatal determinants of the child's development and health). Paediatric and perinatal epidemiology 2008:1-9.

49. EURO-PERISTAT Project. European perinatal health report. 2008, (Department (Government Body no. Section). http://www.europeristat.com/bm.doc/appendix-bdata-tables.pdf

50. Wacholder S, Rothman N, Caporaso N. Population stratification in epidemiologic studies of common genetic variants and cancer: quantification of bias. J Natl Cancer Inst 2000;92:1151-8.

51. Wang Y, Localio R, Rebbeck TR. Evaluating bias due to population stratification in epidemiologic studies of gene-gene or gene-environment interactions. Cancer Epidemiol Biomarkers Prev 2006;15:124-32. 


\title{
${ }^{*}$ Author Agreement
}

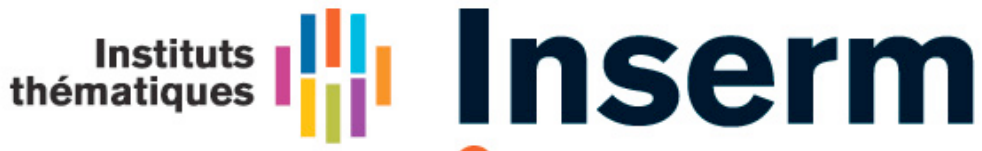 \\ Institut national \\ de la santé et de la recherche médicale}

\author{
Rémy Slama \\ Team leader \\ Team 14
}

Environmental Epidemiology applied to

Fecundity and Reproduction

Inserm U. 823 / Institut Albert Bonniot

Phone: +33 476549402

remy.slama@ujf-grenoble.fr

\author{
Grenoble, November 11, 2009 \\ The Editor \\ Reproductive Toxicology
}

Author agreement

We certify that the work described in the manuscript

"Maternal Fine Particulate Matter Exposure, Polymorphism in XenobioticMetabolizing Genes and Offspring Birthweight"

has not been published previously (except in the form of an abstract), that it is not under consideration for publication elsewhere, that its publication is approved by all authors and tacitly or explicitly by the responsible authorities where the work was carried out, and that, if accepted, it will not be published elsewhere in the same form, in English or in any other language, without the written consent of the copyright-holder.

For the co-authors

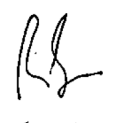

Rémy Slama, PhD

Corresponding author 


\section{${ }^{*}$ Conflict of Interest Statement}

\section{Reproductive Toxicology \\ Conflict of Interest Policy}

Manuscript number (if applicable):

Article Title: Maternal Fine Particulate Matter

Exposure, Polymorphism in Xenobiotic-

Metabolizing Genes and Offspring Birthweight
Author name:

Rémy SLAMA, PhD

\section{Declarations}

Reproductive Toxicology requires that all authors sign a declaration of conflicting interests. If you have nothing to declare in any of these categories then this should be stated.

\section{Conflict of Interest}

A conflicting interest exists when professional judgement concerning a primary interest (such as patient's welfare or the validity of research) may be influenced by a secondary interest (such as financial gain or personal rivalry). It may arise for the authors when they have financial interest that may influence their interpretation of their results or those of others. Examples of potential conflicts of interest include employment, consultancies, stock ownership, honoraria, paid expert testimony, patent applications/registrations, and grants or other funding.

\section{Please state any competing interests}

None.

\section{Funding Source}

All sources of funding should also be acknowledged and you should declare any involvement of study sponsors in the study design; collection, analysis and interpretation of data; the writing of the manuscript; the decision to submit the manuscript for publication. If the study sponsors had no such involvement, this should be stated.

Please state any sources of funding for your research

Inserm and Helmholtz Center Munich.

Signature (a scanned signature is acceptable, but each author must sign)

\section{Print name}<smiles>CCc1ccccc1C</smiles> 
Figure 1: Flow Chart of Study Participants (restricted to singleton births with available birth weight information) of LISA Birth Cohort.

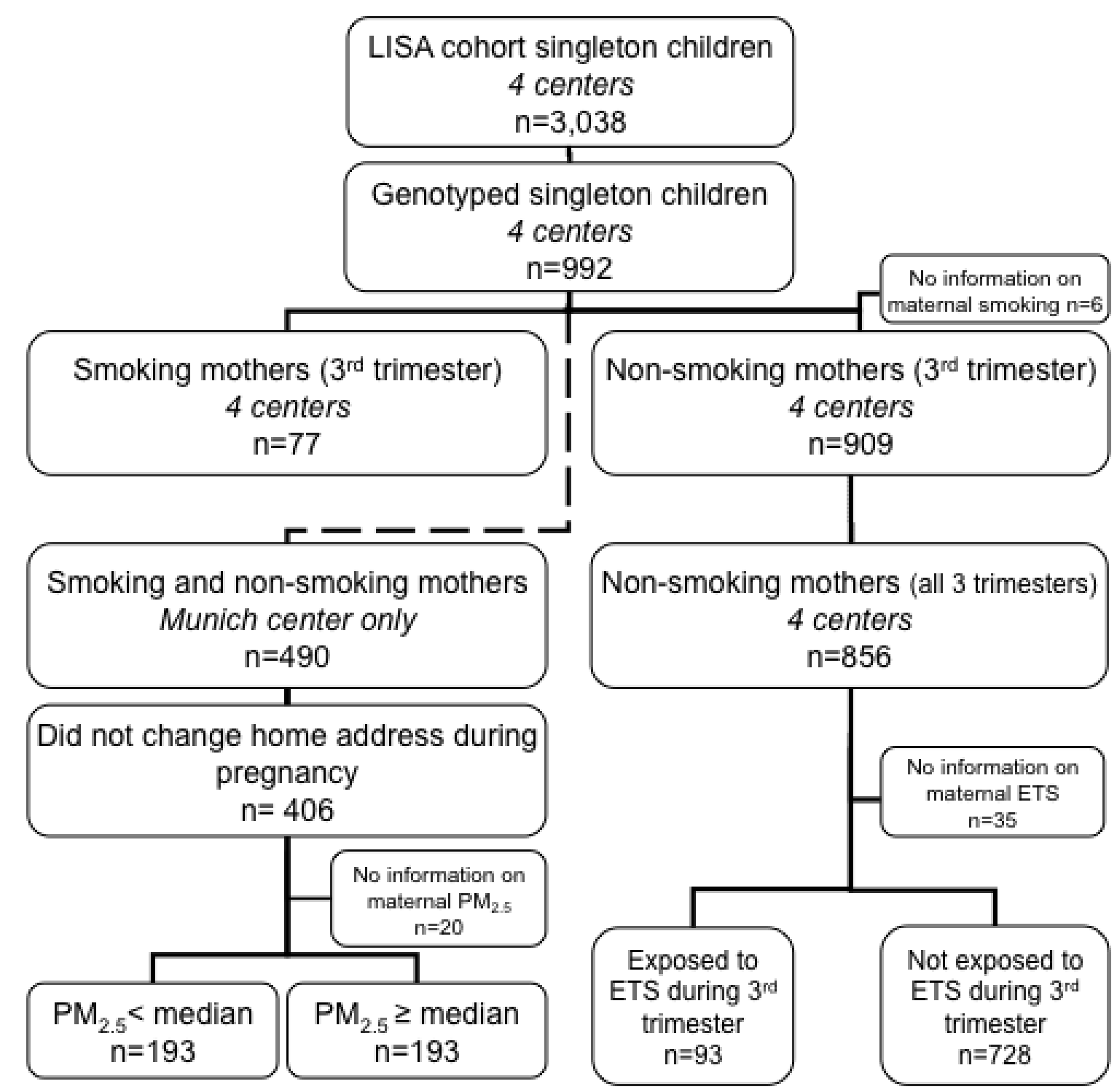

Abbreviations: ETS: Environmental Tobacco Smoke; $\mathrm{PM}_{2.5}$ : Particulate matter with an aerodynamical diameter below $2.5 \mu$. 
Figure 2: Sensitivity analysis; polymorphism-specific adjusted association between $\mathrm{PM}_{2.5}$ exposure, smoking or ETS and birh weight (linear regression models) in LISA birth cohort (Germany, 1997-99). Each bar corresponds to the adjusted estimated effect of exposure on mean birth weight in the group with the considered polymorphism. A) Original analysis excluding birth weights below 2500 g; B) Sensitivity analysis corrected for the exclusion of birth weights below $2500 \mathrm{~g}$ (average of 1,000 bootstrap replications). For GSTP1 and CYP2D6, polymorphism 1 corresponds to the wild type homozygous genotype.

\section{A) Original analysis}

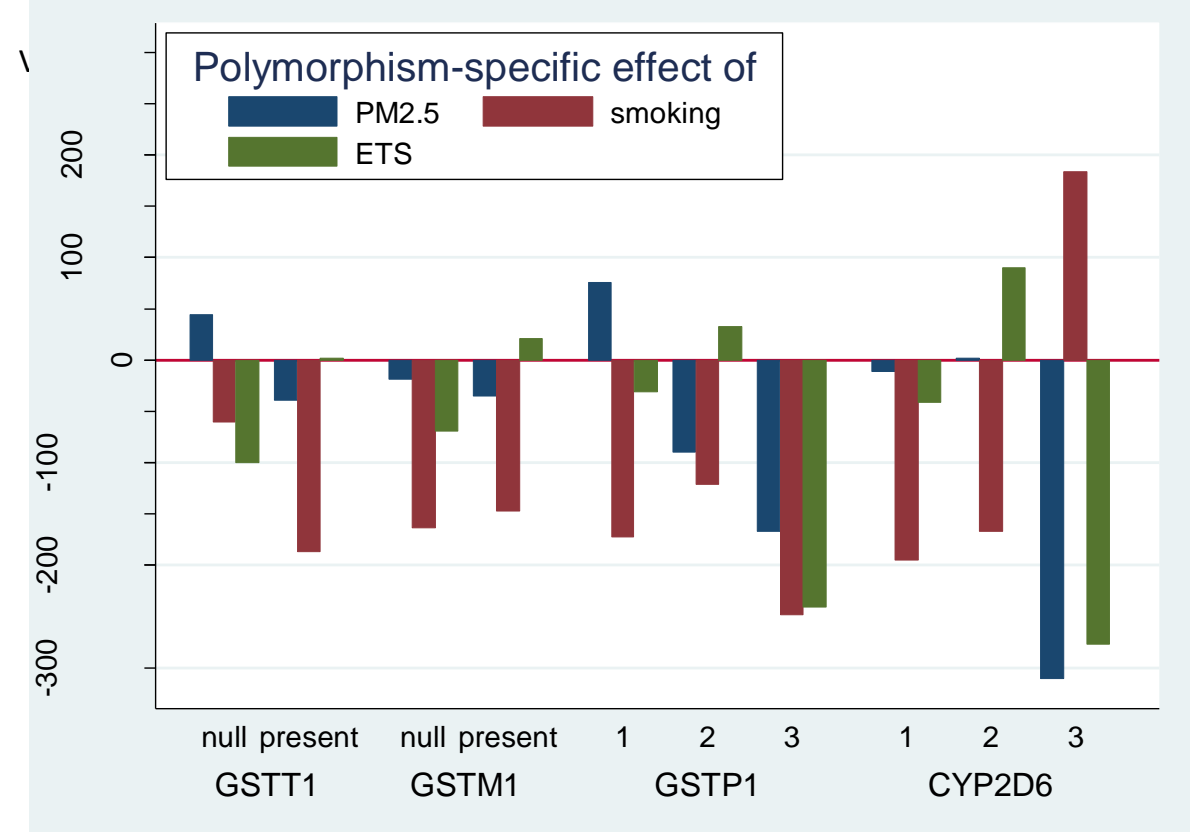

\section{B) Sensitivity analysis}

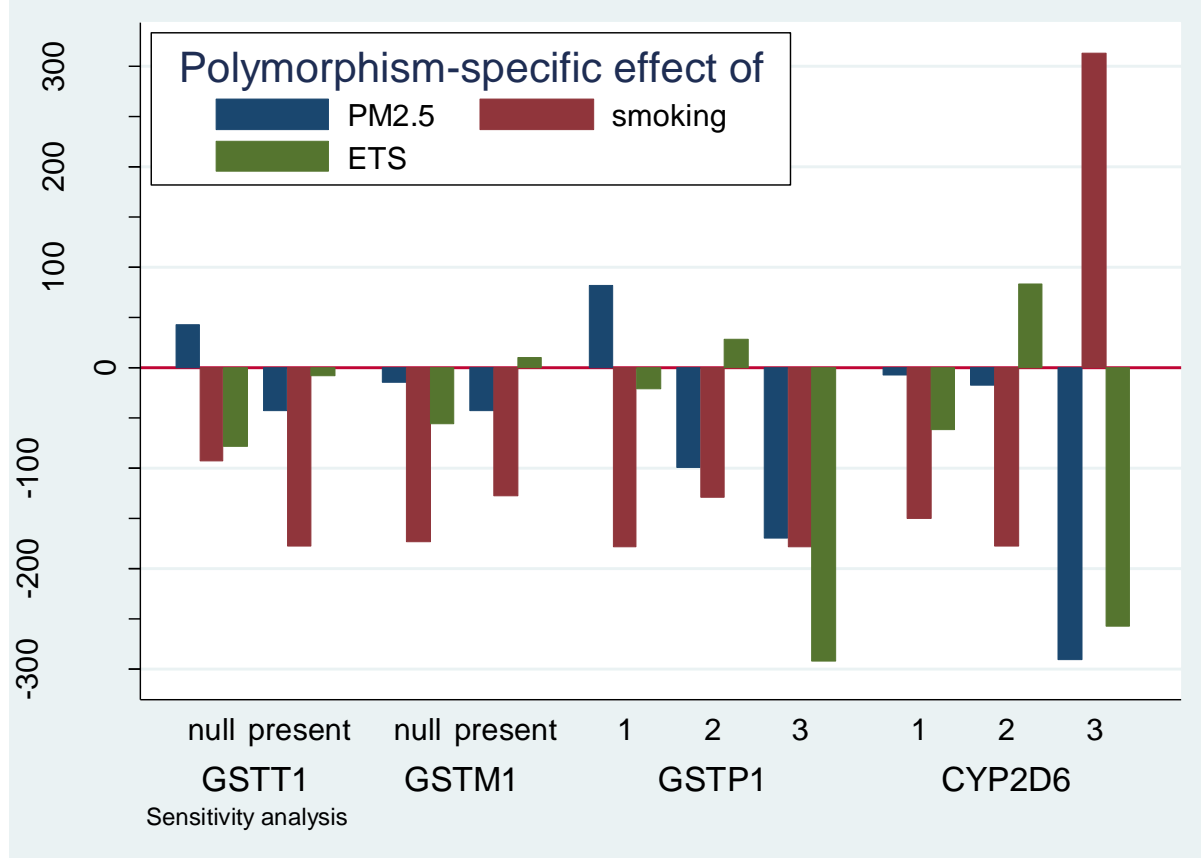



Supplement
Click here to download Supplement: ETS_PM_Genes\&Birth weight in LISA-V11-ReprodTox-Supplement-2010_02_25.doc Click here to download Supplement: ETS_PM_Genes\&Birth weight in LISA-V11-ReprodTox-Supplement-2010_02_25.d0C_ 
TABLES

Table 1: Overview of Previous Gene-Environment Studies of Effects of Atmospheric Pollutants or Active or Passive Smoking on Birth Weight Considering Polymorphisms of Xenobiotics-Metabolizing Genes.

\begin{tabular}{|c|c|c|c|c|c|c|}
\hline Reference & $\begin{array}{l}\text { Environmental } \\
\text { factor }\end{array}$ & Genetic polymorphisms & $\begin{array}{l}\text { Origin of } \\
\text { DNA }\end{array}$ & Outcome & Type of model & Main results \\
\hline Suh, 2007 [10] & $\begin{array}{l}\mathrm{PM}_{10} \text { (above } 90^{\text {th }} \\
\text { centile vs. below } \\
90^{\text {th }} \text { centile) }\end{array}$ & $\begin{array}{l}\text { CYP1A1 Mspl } \\
\text { CYP1A1 Ncol }\end{array}$ & $\begin{array}{l}\text { Maternal } \\
(n=199)\end{array}$ & Birth weight & Additive & $\begin{array}{l}\text { Birth weight change associated with } \mathrm{PM}_{10}: \\
\text {-Mspl: }-349 \mathrm{~g} \text { for TT genotype of CYP1A1 Mspl } \\
\text { polymorphism and }-394 \mathrm{~g} \text { for TC/CC genotype; } \\
\text { - Ncol: }-261 \mathrm{~g} \text { for llelle genotype of CYP1A1 Ncol } \\
\text { polymorphism and }-489 \mathrm{~g} \text { for lleVal/ValVal genotype. }\end{array}$ \\
\hline Wang, 2002 [30] & $\begin{array}{l}\text { Maternal smoking } \\
\text { during pregnancy }\end{array}$ & $\begin{array}{l}\text { CYP1A1 (AA: } \\
\text { homozygous wild type; } \\
\text { aa: homozygous variant } \\
\text { type) } \\
\text { GSTT1 }\end{array}$ & $\begin{array}{l}\text { Maternal } \\
(n=741)\end{array}$ & Birth weight & $\begin{array}{l}\text { Additive (with a } \\
\text { case-control } \\
\text { sampling) }\end{array}$ & $\begin{array}{l}\text { Birth weight change associated with smoking: } \\
\text { CYP1A1: }-252 \mathrm{~g} \text { for } A A \text { polymorphism, }-520 \mathrm{~g} \text { for } A a / a a \\
\text { genotype (interaction test, } \mathrm{P}=0.06 \text { ). } \\
\text { GSTT1: }-285 \mathrm{~g} \text { for present genotype, }-642 \mathrm{~g} \text { for absent } \\
\text { genotype (interaction test, } \mathrm{P}=0.04 \text { ). }\end{array}$ \\
\hline $\begin{array}{l}\text { Grazuleviciene } \\
2009 \text { [39] }\end{array}$ & $\begin{array}{l}\text { Maternal smoking } \\
\text { during pregnancy }\end{array}$ & $\begin{array}{l}\text { GSTT1 } \\
\text { GSTM1 }\end{array}$ & $\begin{array}{l}\text { Maternal } \\
(n=646)\end{array}$ & $\begin{array}{l}\text { Birth } \\
\text { weight }<2,500 \mathrm{~g}\end{array}$ & Multiplicative & $\begin{array}{l}\text { Interaction test between smoking and genetic } \\
\text { polymorphisms: P>0.5 for GSTT1 and GSTM1. }\end{array}$ \\
\hline $\begin{array}{l}\text { Infante-Rivard, } \\
2006[31]\end{array}$ & $\begin{array}{l}\text { Maternal smoking } \\
\text { during } 3^{\text {rd }} \text { trimester } \\
\text { of pregnancy }\end{array}$ & $\begin{array}{l}\text { GSTT1 } \\
\text { GSTM1 } \\
\text { CYP1A } 1 * 2 \mathrm{~A}, 2 \mathrm{~B}, 4 \\
\text { XRCC3 }\end{array}$ & $\begin{array}{l}\text { Newborn } \\
(n=465)\end{array}$ & $\begin{array}{l}\text { Small-for } \\
\text { gestational age } \\
\text { (SGA) birth }\end{array}$ & Multiplicative & $\begin{array}{l}\text { GSTT1: OR of SGA associated with smoking }=0.85 \text { for }+/+ \\
\text { genotype, } 2.77 \text { for }-/+ \text { and } 1.42 \text { for }-/- \text { genotypes (statistical } \\
\text { interaction, } P=0.01 \text { ). } P \text { for statistical interaction }=0.18 \text { for } \\
\text { XRCC3, } P=0.66 \text { for GSTM1, } P=0.98 \text { for } C Y P 1 A 1 * 2 B, P=0.06 \\
\text { for } C Y P 1 A 1 * 4 \text {. }\end{array}$ \\
\hline $\begin{array}{l}\text { Infante-Rivard, } \\
2006[31]\end{array}$ & $\begin{array}{l}\text { Maternal smoking } \\
\text { during } 3^{\text {rd }} \text { trimester } \\
\text { of pregnancy }\end{array}$ & $\begin{array}{l}\text { GSTT1 } \\
\text { GSTM1 } \\
\text { CYP1A1*2A, 2B, } 4 \\
\text { XRCC3 }\end{array}$ & $\begin{array}{l}\text { Maternal } \\
(n=465)\end{array}$ & $\begin{array}{l}\text { Small-for } \\
\text { gestational age } \\
\text { (SGA) birth }\end{array}$ & Multiplicative & $\begin{array}{l}\text { GSTT1: OR of SGA associated with smoking }=1.39 \text { for }+/+ \\
\text { genotype, } 1.93 \text { for }-/+ \text { and } 2.63 \text { for }-/- \text { genotype }(P \text { for } \\
\text { interaction, 0.46). GSTM1: } \mathrm{P} \text { for interaction, } 0.18 \text {. } \\
\text { CYP1A1*2B: } P=0.84 . \text { CYP1A1*4: } P=0.84 . \text { XRCC3: } P=0.03 \text {. }\end{array}$ \\
\hline $\begin{array}{l}\text { Sasaki, } 2008 \\
{[40]}\end{array}$ & $\begin{array}{l}\text { Maternal smoking } \\
\text { during } 2^{\text {nd }} \text { or } 3^{\text {rd }} \\
\text { trimester of } \\
\text { pregnancy }\end{array}$ & $\begin{array}{l}\text { NQO1, } \\
\text { CYP2E1 }\end{array}$ & $\begin{array}{l}\text { Maternal } \\
(n=460)\end{array}$ & $\begin{array}{l}\text { Birth weight } \\
\text { (length and head } \\
\text { circumference } \\
\text { also considered) }\end{array}$ & Additive & $\begin{array}{l}\text { Birth weight change associated with smoking: } \\
\text { NQO1: beta=-77g for Pro*/Ser } \text { or Ser/Ser genotypes; beta= } \\
-199 \mathrm{~g} \text { for Pro/Pro genotype }(\mathrm{P} \text { for interaction, } 0.05) \text {. } \\
\text { CYP2E1: beta=-170 g for } c 1 / c 2 \text { or } c 2 / c 2 \text { genotypes and }-195 \\
\mathrm{~g} \text { for } c 1 / c 1 \text { genotype ( } \mathrm{P} \text { for interaction, } 0.63 \text { ). }\end{array}$ \\
\hline Wu, 2007 [41] & $\begin{array}{l}\text { Passive smoking at } \\
\text { home during } \\
\text { pregnancy (ETS) }\end{array}$ & $\begin{array}{l}\text { CYP1A1 Mspl } \\
\text { EPHX1 (Tyr113His) }\end{array}$ & $\begin{array}{l}\text { Maternal } \\
(\mathrm{n}=680)\end{array}$ & Birth weight & Additive & $\begin{array}{l}\text { Birth weight change associated with ETS: } \\
\text { CYP1A1: beta }=15 \mathrm{~g} \text { for } T / T \text { genotype, }-11 \mathrm{~g} \text { for } T / C \text { genotype } \\
\text { and } 14 \mathrm{~g} \text { for } C / C \text { genotype. } \\
\text { EPHX1: beta= } 2 \mathrm{~g} \text { for Tyr } / T y r \text { genotype, }-104 \mathrm{~g} \text { for } T y r / H i s \\
\text { genotype and }-687 \mathrm{~g} \text { for His/His genotype }\end{array}$ \\
\hline Hong, 2003 [28] & $\begin{array}{l}\text { Passive smoking } \\
\text { (ETS) }\end{array}$ & $\begin{array}{l}\text { GSTT1 } \\
\text { GSTM1 }\end{array}$ & $\begin{array}{l}\text { Maternal } \\
(\mathrm{n}=266)\end{array}$ & Birth weight & Additive & $\begin{array}{l}\text { Birth weight change associated with ETS: } \\
\text { GSTM1: }-11 \mathrm{~g} \text { for wild genotype and }-158 \mathrm{~g} \text { for null genotype }\end{array}$ \\
\hline
\end{tabular}


(interaction test, $\mathrm{P}=0.17$ )

GSTT1: $203 \mathrm{~g}$ for wild genotype and $-236 \mathrm{~g}$ for null genotype interaction test, $\mathrm{P}<0.01$ )

\begin{tabular}{|c|c|c|c|c|c|c|}
\hline This study & $\begin{array}{l}\mathrm{PM}_{2.5} \text { (above } \\
\text { versus below } \\
\text { median) }\end{array}$ & $\begin{array}{l}\text { GSTT1 GSTM1 } \\
\text { GSTP1 lle105Val } \\
\text { CYP2D6 G>A }\end{array}$ & $\begin{array}{l}\text { Newborn } \\
(n=386)\end{array}$ & Birth weight & Additive & $\begin{array}{l}\text { (interaction test, } \mathrm{P}<0.01) \text {. } \\
\text { Birth weight change associated with } \mathrm{PM}_{2.5} \text { exposure: } \\
\text { GSTP1: beta }=-168 \mathrm{~g} \text { in birth weight in children with GSTP1 } \\
{ }^{*} 1 B /{ }^{*} 1 B \text { mutant genotype, }-90 \mathrm{~g} \text { in the heterozygous } \\
\text { genotype and }+76 \mathrm{~g} \text { in the homozygous wild type genotype } \\
\text { (interaction test, } \mathrm{P}=0.05) \text {. No effect measure modification } \\
\text { with } \mathrm{PM}_{2.5} \text { was detected for the other genetic polymorphisms } \\
(\mathrm{P} \geq 0.12) \text {. }\end{array}$ \\
\hline This study & Active smoking & $\begin{array}{l}\text { GSTT1 GSTM1 } \\
\text { GSTP1 lle105Val } \\
\text { CYP2D6 G>A }\end{array}$ & $\begin{array}{l}\text { Newborn } \\
(n=986)\end{array}$ & Birth weight & Additive & $\begin{array}{l}\mathrm{P} \text { for interaction }=0.25 \text { for } G S T T 1, \mathrm{P}=0.86 \text { for } G S T M 1, \mathrm{P}=0.71 \\
\text { for } G \text { STP } 1 \text { and } \mathrm{P}=0.19 \text { for } C Y P 2 D 6 \text {. }\end{array}$ \\
\hline This study & $\begin{array}{l}\text { Passive smoking } \\
\text { (ETS) }\end{array}$ & $\begin{array}{l}\text { GSTT1 GSTM1 } \\
\text { GSTP1 lle105Val } \\
\text { CYP2D6 G>A }\end{array}$ & $\begin{array}{l}\text { Newborn } \\
(n=821)\end{array}$ & Birth weight & Additive & $\begin{array}{l}\mathrm{P} \text { for interaction }=0.38 \text { for } G S T T 1, \mathrm{P}=0.30 \text { for } G S T M 1, \mathrm{P}=0.13 \\
\text { for GSTP1 and } \mathrm{P}=0.06 \text { for } C Y P 2 D 6 \text {. }\end{array}$ \\
\hline
\end{tabular}

Abbreviation: $\mathrm{PM}_{10}$ : particulate matter with an aerodynamical diameter lower than $10 \mu$. 
Table 2: Characteristics of the LISA birth cohort with Information on Genotypes, Stratified According to Environmental Tobacco Smoke (ETS, Restricted to Non-Smoking Women), Pregnancy $\mathrm{PM}_{2.5}$ Average and Active Smoking.

\begin{tabular}{|c|c|c|c|c|c|c|c|c|c|c|c|c|c|c|c|}
\hline \multirow{3}{*}{ Characteristic } & \multicolumn{5}{|c|}{ ETS (n=821) } & \multicolumn{5}{|c|}{$\mathrm{PM}_{2.5}(\mathrm{n}=386)$} & \multicolumn{4}{|c|}{ Active smoking $(\mathrm{n}=986)$} & \multirow{3}{*}{$p$} \\
\hline & \multicolumn{2}{|c|}{ No $(n=728)$} & \multicolumn{2}{|c|}{ Yes $(n=93)$} & \multirow[t]{2}{*}{$p$} & \multicolumn{2}{|c|}{$<$ median $(\mathrm{n}=193)$} & \multicolumn{2}{|c|}{$\geq$ median $(n=193)$} & \multirow[t]{2}{*}{$p$} & \multicolumn{2}{|c|}{ No $(n=909)$} & \multicolumn{2}{|c|}{ Yes $(n=77)$} & \\
\hline & $\mathrm{n}$ & $\%$ & $\mathrm{n}$ & $\%$ & & $\mathrm{n}$ & $\%$ & $n$ & $\%$ & & $\mathrm{n}$ & $\%$ & $\mathrm{n}$ & $\begin{array}{l}\text { 7) } \\
\% \\
\end{array}$ & \\
\hline \multicolumn{16}{|l|}{ Genetic polymorphisms } \\
\hline GSTT1 null & & & & & 0.73 & & & & & 0.52 & & & & & 0.07 \\
\hline present & 589 & 81 & 76 & 83 & & 157 & 82 & 152 & 79 & & 735 & 81 & 56 & 73 & \\
\hline null & 137 & 19 & 16 & 17 & & 35 & 18 & 40 & 21 & & 171 & 19 & 21 & 27 & \\
\hline GSTM1 & & & & & 0.07 & & & & & 0.72 & & & & & 0.25 \\
\hline present & 369 & 51 & 56 & 61 & & 102 & 53 & 98 & 51 & & 461 & 51 & 34 & 44 & \\
\hline null & 356 & 49 & 36 & 39 & & 90 & 47 & 93 & 49 & & 444 & 49 & 43 & 56 & \\
\hline GSTP1 lle105Val & & & & & 0.80 & & & & & 0.84 & & & & & 0.48 \\
\hline$w t / w t$ & 322 & 44 & 38 & 41 & & 88 & 46 & 83 & 43 & & 398 & 44 & 30 & 39 & \\
\hline$w t{ }^{*} 1 B$ & 318 & 44 & 44 & 47 & & 83 & 43 & 89 & 46 & & 407 & 45 & 40 & 52 & \\
\hline${ }^{*} 1 B /{ }^{*} 1 B$ & 86 & 12 & 11 & 12 & & 21 & 11 & 21 & 11 & & 102 & 11 & 7 & 9 & \\
\hline CYP2D 6 G>A & & & & & 0.33 & & & & & 0.34 & & & & & 0.86 \\
\hline$w t / w t$ & 447 & 62 & 50 & 55 & & 117 & 62 & 112 & 60 & & 552 & 61 & 48 & 63 & \\
\hline$w t /{ }^{*} 4$ & 226 & 31 & 32 & 35 & & 54 & 29 & 64 & 34 & & 286 & 32 & 24 & 32 & \\
\hline$* 4 /{ }^{*} 4$ & 48 & 7 & 9 & 10 & & 18 & 10 & 12 & 6 & & 62 & 7 & 4 & 5 & \\
\hline \multicolumn{16}{|l|}{ Characteristics of pregnancy } \\
\hline Gestational duration (weeks) & & & & & 0.58 & & & & & 0.68 & & & & & 0.58 \\
\hline 37 & 24 & 3 & 4 & 4 & & 3 & 2 & 8 & 4 & & 31 & 3 & 4 & 5 & \\
\hline 38 & 68 & 9 & 8 & 9 & & 19 & 10 & 15 & 8 & & 86 & 9 & 6 & 8 & \\
\hline 39 & 149 & 20 & 18 & 19 & & 36 & 19 & 33 & 17 & & 189 & 21 & 17 & 22 & \\
\hline 40 & 266 & 37 & 32 & 34 & & 69 & 36 & 73 & 38 & & 325 & 36 & 21 & 27 & \\
\hline 41 & 161 & 22 & 18 & 19 & & 43 & 22 & 40 & 21 & & 195 & 21 & 25 & 19 & \\
\hline$\geq 42$ & 60 & 8 & 13 & 14 & & 23 & 12 & 24 & 12 & & 83 & 9 & 10 & 13 & \\
\hline Sex of the child & & & & & 0.29 & & & & & 0.84 & & & & & 0.87 \\
\hline Female & 340 & 47 & 38 & 41 & & 85 & 44 & 87 & 45 & & 416 & 46 & 36 & 47 & \\
\hline Male & 388 & 53 & 55 & 59 & & 108 & 56 & 106 & 55 & & 493 & 54 & 41 & 53 & \\
\hline Birth weight & & & & & 0.95 & & & & & 0.40 & & & & & 0.05 \\
\hline$<3000 \mathrm{~g}$ & 80 & 11 & 11 & 12 & & 24 & 12 & 30 & 16 & & 102 & 11 & 17 & 22 & \\
\hline $3000-3249 \mathrm{~g}$ & 140 & 19 & 15 & 16 & & 38 & 20 & 37 & 19 & & 171 & 19 & 15 & 19 & \\
\hline $3250-3499 \mathrm{~g}$ & 165 & 23 & 20 & 22 & & 43 & 22 & 36 & 19 & & 199 & 22 & 17 & 22 & \\
\hline $3500-3999 \mathrm{~g}$ & 251 & 34 & 34 & 37 & & 62 & 32 & 73 & 38 & & 316 & 35 & 22 & 29 & \\
\hline$\geq 4000 \mathrm{~g}$ & 92 & 13 & 13 & 14 & & 26 & 13 & 17 & 9 & & 121 & 13 & 6 & 8 & \\
\hline
\end{tabular}




\begin{tabular}{|c|c|c|c|c|c|c|c|c|c|c|c|c|c|c|c|}
\hline Mean (g) & 3502 & & 3515 & & $0.78^{\mathrm{a}}$ & 3480 & & 3450 & & $0.42^{\mathrm{a}}$ & 3508 & & 370 & & $0.008^{\mathrm{a}}$ \\
\hline Period of conception & & & & & & & & & & & & & & & \\
\hline January to March & 162 & 22 & 21 & 23 & & 45 & 23 & 33 & 17 & & 204 & 22 & 17 & 22 & \\
\hline April to June & 188 & 26 & 26 & 28 & & 55 & 29 & 54 & 29 & & 238 & 26 & 24 & 31 & \\
\hline July to September & 169 & 23 & 20 & 22 & & 33 & 17 & 66 & 34 & & 213 & 23 & 15 & 19 & \\
\hline October to December & 209 & 29 & 26 & 28 & & 60 & 31 & 40 & 21 & & 254 & 28 & 21 & 27 & \\
\hline Maternal age & & & & & 0.01 & & & & & 0.81 & & & & & 0.001 \\
\hline$<25$ years & 34 & 5 & 5 & 5 & & 2 & 1.0 & 5 & 3 & & 47 & 5 & 13 & 17 & \\
\hline $25-29$ years & 209 & 29 & 41 & 44 & & 38 & 20 & 37 & 19 & & 272 & 30 & 22 & 29 & \\
\hline $30-34$ years & 356 & 49 & 29 & 31 & & 102 & 53 & 105 & 55 & & 420 & 46 & 25 & 32 & \\
\hline $35-39$ years & 113 & 16 & 16 & 17 & & 46 & 24 & 40 & 21 & & 149 & 16 & 13 & 17 & \\
\hline$\geq 40$ years & 15 & 2 & 2 & 2 & & 5 & 3 & 5 & 3 & & 19 & 2 & 4 & 5 & \\
\hline Maternal parity & & & & & 0.01 & & & & & 0.002 & & & & & 0.24 \\
\hline 0 & 384 & 53 & 61 & 67 & & 85 & 44 & 115 & 60 & & 490 & 54 & 47 & 61 & \\
\hline$\geq 1$ & 343 & 47 & 30 & 33 & & 108 & 56 & 78 & 40 & & 416 & 46 & 30 & 39 & \\
\hline $\begin{array}{l}\text { Maternal tobacco smoking }\left(3^{\text {rd }}\right. \\
\text { trimester) }\end{array}$ & & & & & N.A. & & & & & 0.99 & & & & & N.A. \\
\hline No & 728 & 100 & 93 & 100 & & 177 & 92 & 178 & 92 & & 909 & 100 & 0 & 0 & \\
\hline Yes & 0 & 0 & 0 & 0 & & 15 & 8 & 15 & 8 & & 0 & 0 & 77 & 100 & \\
\hline Maternal ETS ( $3^{\text {rd }}$ trimester) & & & & & N.A. & & & & & 0.22 & & & & & $<0.001$ \\
\hline No & 694 & 100 & 0 & 0 & & 168 & 91 & 157 & 87 & & 764 & 88 & 29 & 40 & \\
\hline Yes & 0 & 0 & 132 & 100 & & 17 & 9 & 24 & 13 & & 106 & 12 & 43 & 60 & \\
\hline Maternal education & & & & & 0.001 & & & & & 0.005 & & & & & $<0.001$ \\
\hline Vocational school & 50 & 7 & 6 & 7 & & 17 & 9 & 9 & 5 & & 65 & 7 & 7 & 9 & \\
\hline High school ("Abitur") & 400 & 55 & 31 & 34 & & 94 & 49 & 126 & 65 & & 456 & 50 & 17 & 22 & \\
\hline Maternal height (cm) & & & & & 0.37 & & & & & 0.04 & & & & & 0.90 \\
\hline$\leq 160$ & 69 & 10 & 12 & 13 & & 24 & 13 & 12 & 6 & & 96 & 11 & 7 & 9 & \\
\hline $161-170$ & 399 & 55 & 55 & 60 & & 110 & 58 & 102 & 53 & & 503 & 56 & 44 & 58 & \\
\hline $171-180$ & 240 & 33 & 23 & 25 & & 55 & 29 & 74 & 39 & & 284 & 32 & 23 & 30 & \\
\hline$>180$ & 12 & 2 & 2 & 2 & & 1 & 1 & 3 & 2 & & 15 & 2 & 2 & 3 & \\
\hline Maternal pre-pregnancy weight & & & & & 0.22 & & & & & 0.26 & & & & & 0.46 \\
\hline$\leq 50 \mathrm{~kg}$ & 29 & 4 & 4 & 4 & & 11 & 6 & 9 & 5 & & 40 & 4 & 6 & 8 & \\
\hline $51-60 \mathrm{~kg}$ & 269 & 38 & 29 & 31 & & 68 & 36 & 84 & 44 & & 339 & 38 & 26 & 35 & \\
\hline $61-70 \mathrm{~kg}$ & 262 & 37 & 30 & 32 & & 76 & 40 & 59 & 31 & & 310 & 35 & 22 & 30 & \\
\hline $71-80 \mathrm{~kg}$ & 94 & 13 & 16 & 17 & & 22 & 12 & 21 & 11 & & 127 & 14 & 14 & 19 & \\
\hline$>80 \mathrm{~kg}$ & 63 & 9 & 14 & 15 & & 11 & 6 & 17 & 9 & & 81 & 9 & 6 & 8 & \\
\hline Maternal pre-pregnancy BMI & & & & & 0.02 & & & & & 0.10 & & & & & $<0.001$ \\
\hline
\end{tabular}


$\leq 18 \mathrm{~kg} / \mathrm{m}^{2}$

$18<\mathrm{BMI} \leq 20 \mathrm{~kg} / \mathrm{m}^{2}$

$20<\mathrm{BMI} \leq 22.5 \mathrm{~kg} / \mathrm{m}^{2}$

$22.5<\mathrm{BMl} \leq 25 \mathrm{~kg} / \mathrm{m}^{2}$

$25<\mathrm{BMI} \leq 30 \mathrm{~kg} / \mathrm{m}^{2}$

$30<$ BMI $\left(\mathrm{kg} / \mathrm{m}^{2}\right)$

Centre

Munich

Leipzig

Wesel

Bad Honef

$\begin{array}{rr}1 & 1 \\ 5 & 5 \\ 41 & 44 \\ 22 & 24 \\ 16 & 17 \\ 8 & 9\end{array}$

$32 \quad 34$

$37 \quad 40$

$10 \quad 11$

$\begin{array}{rrrr}2 & 1 & 7 & 4 \\ 33 & 17 & 43 & 22 \\ 74 & 38 & 84 & 44 \\ 42 & 22 & 27 & 14 \\ 29 & 15 & 22 & 11 \\ 13 & 7 & 10 & 5\end{array}$

0.003

$93 \quad 100$

193

100

$\begin{array}{rrr}17 & 2 & 8 \\ 157 & 17 & 11 \\ 368 & 40 & 20 \\ 179 & 20 & 16 \\ 122 & 13 & 12 \\ 66 & 7 & 10\end{array}$

$\begin{array}{rr}8 & 10 \\ 11 & 14 \\ 20 & 26 \\ 16 & 21 \\ 12 & 16 \\ 10 & 13\end{array}$

0

14

1

16

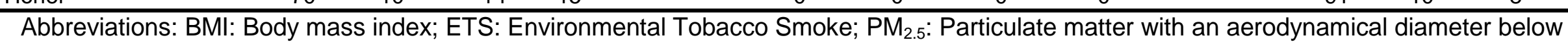
$2.5 \mu$.

${ }^{a} \mathrm{p}$-value of Student's t test. All other $\mathrm{p}$-values correspond to $\chi^{2}$ tests. 
Table 3: Estimated Effect of Genetic Polymorphisms, $\mathrm{PM}_{2.5}$ Exposure, Active Smoking or ETS on Birth Weight among Genotyped Children of the LISA Cohort. The effect of each factor was estimated in a separate regression model not adjusted for the other exposure factors but adjusted for potential confounders.

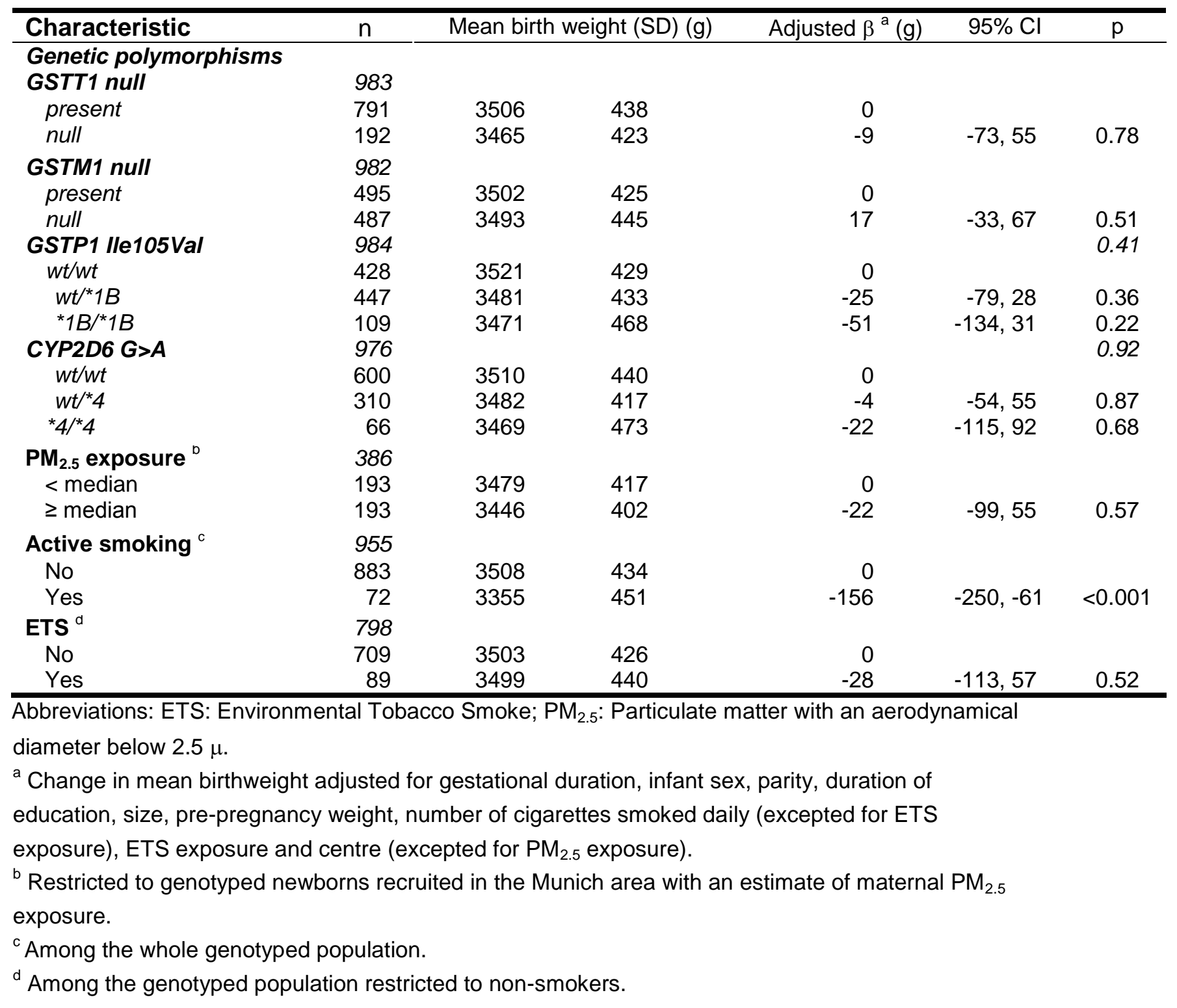


Table 4: Association Between Maternal $\mathrm{PM}_{2.5}$ Exposure (- indicates subjects below $\mathrm{PM}_{2.5}$ median level and + those above $\mathrm{PM} 2.5$ median level) and Mean Birth Weight according to Infant Genetic Polymorphisms, among 386 Newborns from Munich Center of the LISA Cohort.

\begin{tabular}{|c|c|c|c|c|c|c|c|c|c|}
\hline \multirow[t]{2}{*}{ Polymorphism } & \multirow[t]{2}{*}{$\mathrm{PM}_{2.5}$} & \multirow[t]{2}{*}{$\bar{n}$} & \multirow{2}{*}{$\begin{array}{c}\text { Mean birth } \\
\text { weight (SD), g }\end{array}$} & \multirow[t]{2}{*}{$\beta^{a}(g)$} & \multirow[t]{2}{*}{$\mathbf{p}$} & \multicolumn{4}{|c|}{ Effect of $\mathrm{PM}_{2.5}$} \\
\hline & & & & & & $\beta^{a, b}(\mathbf{g})$ & $95 \% \mathrm{Cl}$ & $\mathbf{p}$ & Interaction $^{d}$ \\
\hline GSTT1 null & & & & & $0.24^{c}$ & & & & 0.40 \\
\hline \multirow{2}{*}{ present } & - & 144 & 3480 (419) & 0 (ref) & & 0 (ref) & & & \\
\hline & + & 140 & 3420 (414) & -39 & 0.38 & -39 & $-127,48$ & 0.38 & \\
\hline \multirow[t]{2}{*}{ null } & - & 32 & $3510(450)$ & 42 & 0.55 & 0 (ref) & & & \\
\hline & + & 37 & 3550 (327) & 86 & 0.20 & 44 & $-126,213$ & 0.61 & \\
\hline GSTM1 null & & & & & $0.43^{c}$ & & & & 0.83 \\
\hline \multirow[t]{2}{*}{ present } & - & 96 & 3470 (344) & 0 (ref) & & 0 (ref) & & & \\
\hline & + & 92 & 3430 (425) & -35 & 0.51 & -35 & $-139,69$ & 0.51 & \\
\hline \multirow[t]{2}{*}{ null } & - & 80 & 3500 (505) & 44 & 0.42 & 0 (ref) & & & \\
\hline & + & 84 & 3450 (374) & 26 & 0.63 & -19 & $-131,94$ & 0.75 & \\
\hline GSTP1 Ile105Val & & & & & $0.14^{c}$ & & & & 0.05 \\
\hline \multirow[t]{2}{*}{$w t / w t$} & - & 81 & 3470 (439) & 0 (ref) & & 0 (ref) & & & \\
\hline & + & 80 & 3540 (378) & 76 & 0.18 & 76 & $-36,188$ & 0.18 & \\
\hline \multirow[t]{2}{*}{$w t /{ }^{*} 1 B$} & - & 75 & 3480 (422) & 32 & 0.57 & 0 (ref) & & & \\
\hline & + & 79 & 3380 (399) & -58 & 0.31 & -90 & $-203,24$ & 0.12 & \\
\hline \multirow[t]{2}{*}{${ }^{*} 1 B /{ }^{*} 1 B$} & - & 20 & 3600 (373) & 54 & 0.54 & 0 (ref) & & & \\
\hline & + & 19 & $3290(414)$ & -114 & 0.21 & -168 & $-395,59$ & 0.15 & \\
\hline CYP2D6 G>A & & & & & $0.38^{c}$ & & & & 0.12 \\
\hline \multirow[t]{2}{*}{$w t / w t$} & - & 108 & 3500 (432) & 0 (ref) & & 0 (ref) & & & \\
\hline & + & 106 & 3460 (430) & -12 & 0.85 & -12 & $-109,85$ & 0.85 & \\
\hline \multirow[t]{2}{*}{$w t /{ }^{*} 4$} & - & 50 & $3460(400)$ & -26 & 0.78 & 0 (ref) & & & \\
\hline & + & 57 & 3470 (350) & -24 & 0.74 & 2 & $-134,137$ & 0.98 & \\
\hline \multirow[t]{2}{*}{$* 4 / * 4$} & - & 15 & 3520 (384) & 74 & 0.39 & 0 (ref) & & & \\
\hline & + & 10 & 3180 (302) & -237 & 0.05 & -311 & $-590,-31$ & 0.03 & \\
\hline
\end{tabular}

Abbreviation: $\mathrm{PM}_{2.5}$ : Particulate matter with an aerodynamical diameter below $2.5 \mu$.

${ }^{a}$ Parameter (grams) of the linear regression models adjusted for gestational duration, infant sex, maternal active (number of cigarettes) and passive smoking, parity, duration of education, size, pre-pregnancy weight.

${ }^{\mathrm{b}}$ Effect of $\mathrm{PM}_{2.5}$ exposure (above (+) versus below (-) median) within each polymorphism.

${ }^{c}$ Heterogeneity test across all categories (Wald test).

${ }^{d}$ Interaction tests were performed through a Wald test of the significance of the interaction terms in the model. 
Table 5: Association between Maternal Active Smoking during Third Trimester of Pregnancy and Mean Birth Weight according to Infant Genetic Polymorphisms (986 Singleton Births from Munich and Leipzig Centers of LISA Cohort).

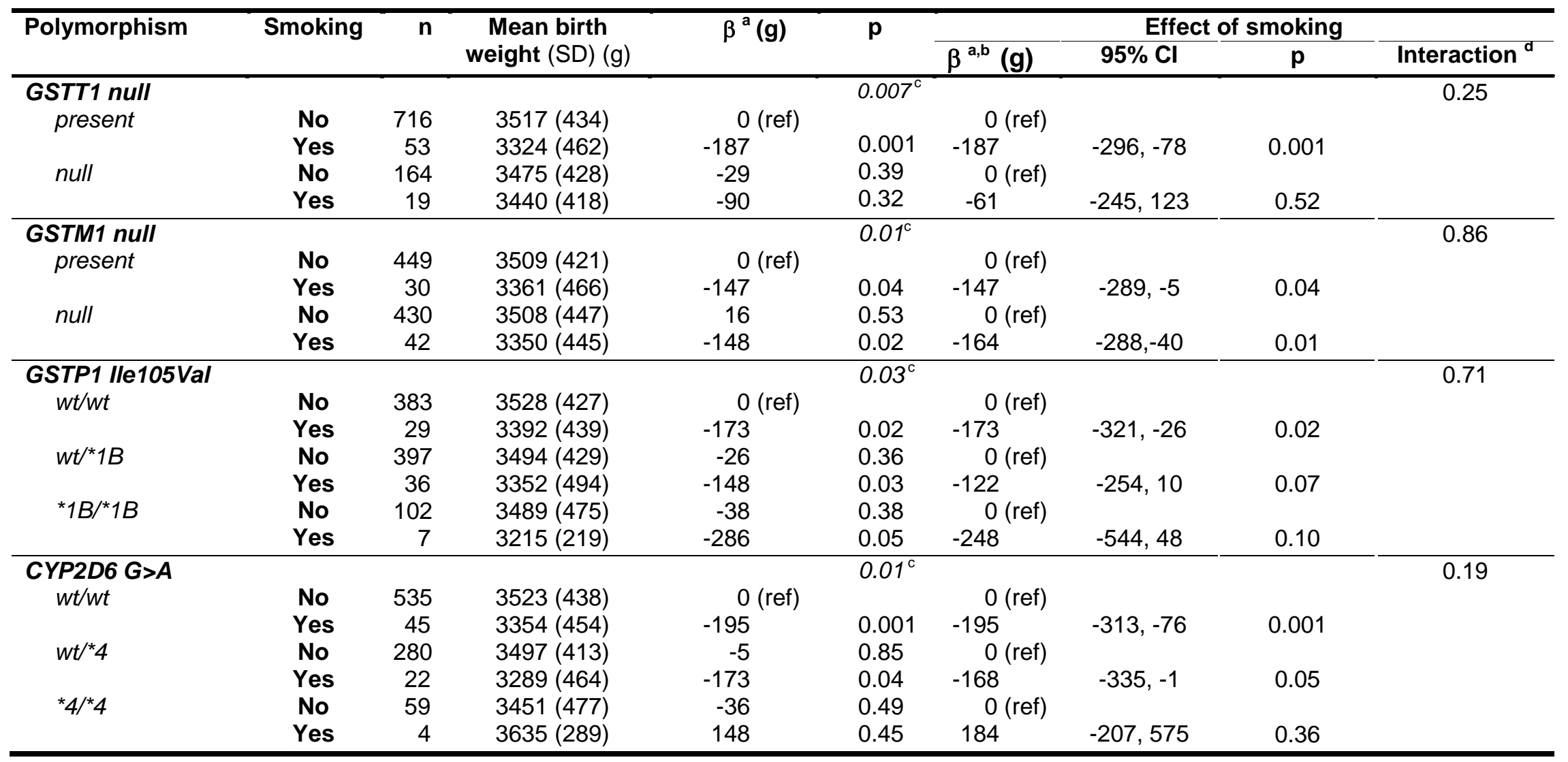

Abbreviation: $\mathrm{PM}_{2.5}$ : Particulate matter with an aerodynamical diameter below $2.5 \mu$.

${ }^{a}$ Parameter (grams) of the linear regression models adjusted for gestational duration, infant sex, parity, duration of education, size, pre-pregnancy weight and centre.

${ }^{b}$ Effect of active smoking (reference, non-smoking women) within each polymorphism.

${ }^{c}$ Heterogeneity test across all categories (Wald test).

${ }^{d}$ Interaction tests were performed through a Wald test of the significance of the interaction terms in the model. 
Table 6: Association between Maternal Passive Smoking and mean Birthweight According to Genetic Polymorphisms, among 826 Non-

Smoking Women from Munich and Leipzig Centers of LISA Cohort.

\begin{tabular}{|c|c|c|c|c|c|c|c|c|c|}
\hline \multirow[t]{2}{*}{ Polymorphism } & \multirow[t]{2}{*}{ ETS } & \multirow[t]{2}{*}{$\mathbf{n}$} & \multirow{2}{*}{$\begin{array}{c}\text { Mean birth } \\
\text { weight (SD) (g) }\end{array}$} & \multirow[t]{2}{*}{$\beta^{a}(g)$} & \multirow[t]{2}{*}{$p$} & \multicolumn{4}{|c|}{ Effect of ETS } \\
\hline & & & & & & $\beta^{a, b}(g)$ & $95 \% \mathrm{Cl}$ & $\mathbf{p}$ & Interaction $^{\mathrm{d}}$ \\
\hline GSTT1 null & & 795 & & & $0.62^{c}$ & & & & 0.38 \\
\hline \multirow[t]{2}{*}{ present } & No & 575 & 3507 (428) & 0 (ref) & & 0 (ref) & & & \\
\hline & Yes & 72 & 3526 (455) & -2 & 0.98 & & $-96,93$ & 0.98 & \\
\hline \multirow[t]{2}{*}{ null } & No & 132 & $3483(418)$ & -20 & 0.59 & 0 (ref) & & & \\
\hline & Yes & 16 & 3431 (314) & -120 & 0.22 & -100 & $-298,98$ & 0.32 & \\
\hline GSTM1 null & & 794 & & & $0.45^{c}$ & & & & 0.30 \\
\hline \multirow[t]{2}{*}{ Present } & No & 359 & 3490 (407) & 0 (ref) & & 0 (ref) & & & \\
\hline & Yes & 54 & $3512(424)$ & 21 & 0.70 & 21 & $-89,131$ & 0.70 & \\
\hline \multirow[t]{2}{*}{ null } & No & 347 & 3515 (446) & 41 & 0.15 & 0 (ref) & & & \\
\hline & Yes & 34 & 3502 (452) & -29 & 0.67 & -70 & $-205,64$ & 0.31 & \\
\hline GSTP1 Ile105Val & & 797 & & & $0.29^{c}$ & & & & 0.13 \\
\hline \multirow[t]{2}{*}{$w t / w t$} & No & 313 & 3524 (408) & 0 (ref) & & 0 (ref) & & & \\
\hline & Yes & 35 & 3491 (393) & -31 & 0.65 & -31 & $-164,103$ & 0.65 & \\
\hline \multirow[t]{2}{*}{$w t /{ }^{*} 1 B$} & No & 309 & 3485 (434) & -36 & 0.24 & 0 (ref) & & & \\
\hline & Yes & 43 & 3531 (425) & -3 & 0.96 & 33 & $-90,156$ & 0.60 & \\
\hline \multirow[t]{2}{*}{${ }^{*} 1 B /{ }^{*} 1 B$} & No & 86 & 3490 (461) & -25 & 0.59 & 0 (ref) & & & \\
\hline & Yes & 11 & 3398 (632) & -267 & 0.02 & -241 & $-481,-2$ & 0.05 & \\
\hline CYP2D6 G>A & & 789 & & & $0.25^{\mathrm{c}}$ & & & & 0.06 \\
\hline \multirow[t]{2}{*}{$w t / w t$} & No & 435 & 3521 (429) & 0 (ref) & & 0 (ref) & & & \\
\hline & Yes & 38 & 3505 (439) & -41 & 0.48 & -41 & $-155,73$ & 0.48 & \\
\hline \multirow[t]{2}{*}{$w t /{ }^{*} 4$} & No & 221 & $3476(400)$ & -21 & 0.51 & 0 (ref) & & & \\
\hline & Yes & 31 & 3595 (478) & 69 & 0.33 & 90 & $-54,234$ & 0.22 & \\
\hline \multirow[t]{2}{*}{$* 4 /{ }^{*} 4$} & No & 46 & 3449 (398) & -16 & 0.78 & 0 (ref) & & & \\
\hline & Yes & 8 & $3414(604)$ & -294 & 0.03 & -278 & $-562,7$ & 0.06 & \\
\hline
\end{tabular}

Abbreviation: ETS: Environmental Tobacco Smoke; $\mathrm{PM}_{2.5}$ : Particulate matter with an aerodynamical diameter below $2.5 \mu$.

${ }^{a}$ Parameter (grams) of the linear regression models adjusted for gestational duration, infant sex, parity, duration of education, size, pre-pregnancy weight and centre.

${ }^{b}$ Adjusted effect of ETS on mean birthweight within each polymorphism.

${ }^{c}$ Heterogeneity test across all categories (Wald test).

${ }^{d}$ Interaction tests were performed through a Wald test of the significance of the interaction terms in the model. 


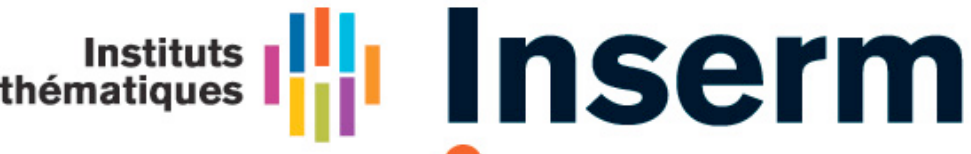 \\ Institut national \\ de la santé et de la recherche médicale
}

\author{
Rémy Slama \\ Team leader \\ Team 14 \\ Environmental Epidemiology applied to \\ Fecundity and Reproduction \\ Inserm U. 823 / Institut Albert Bonniot \\ Phone: +33 476549402 \\ remy.slama@ujf-grenoble.fr
}

\author{
Grenoble, November 11, 2009 \\ The Editor \\ Reproductive Toxicology
}

Dear Editor,

We are pleased to submit to Reproductive Toxicology an original contribution entitled

\section{"Maternal Fine Particulate Matter Exposure, Polymorphism in Xenobiotic- Metabolizing Genes and Offspring Birthweight"}

This study is one of the first to explore effect-measure modifications between maternal exposure to atmospheric pollutants and genetic polymorphisms, for effects on birth weight. It follows a previous publication in which we reported associations between maternal exposure to fine particulate matter and birth weight, without consideration of genetic polymorphisms (Slama et al., EHP, 2007).

One strength of our study is the land-use regression approach based on a measurement campaign of air pollution at 40 sites used to assess exposure to fine particulate matter, which has a fine spatial resolution. In contrast, the only previous study on this topic (Suh, Reprod Toxicol, 2007) relied on air quality monitoring stations to assess exposure, an approach limited by the poor spatial density of air quality monitoring networks. Another originality of our approach lies in the consideration of gene-environment interactions with several environmental factors with similar pathways of action; indeed, we tried to "replicate" the effect measure modification between air pollution exposure and GSTP1 polymorphism with two additional exposure variables: passive and active smoking. This approach might prove useful in the context of geneenvironment (and possibly gene-environment-wide) interaction studies when several exposure factors with similar mechanisms of action have been assessed in one population, but no independent population with similar information is available for replication purposes.

Your journal has published the only study that addressed the question of gene-environment interactions for effects of Particulate Matter on birth weight (Suh et al., Reprod Toxicol, 2007). For this reason, we believe that our manuscript is particularly suited to your journal.

Sincerely,

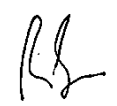

Rémy Slama, PhD

Corresponding author 
Ref.: Ms. No. 2719

Maternal Fine Particulate Matter Exposure, Polymorphism in Xenobiotic-Metabolizing Genes and Offspring Birthweight

Reproductive Toxicology

\section{Reply to the reviewers}

25 Feb. 2010

Reproductive Toxicology

\section{Reviewer \# I:}

\section{GENERAL COMMENTS:}

I.I) The paper is well presented and the objectives of the report are of interest. Nevertheless, the conclusions are weakened by numbers that are either small or very small when assessing heterogeneity of association according to genotype. The conclusions are appropriately prudent, but this hardly compensates for the fact that the limited sample size probably cannot support the demonstration of the hypotheses. Given also that the same mechanisms of action are postulated for the 3 studied exposure variables, it becomes difficult to isolate the effect of any, in particular, ETS and active smoking.

Reply: An originality of the article is indeed the fact that we considered gene-environment interactions with 3 different exposure variables (fine particulate matter, passive smoking (ETS) and active smoking). The reviewer rightly points that effects of ETS and active smoking may be difficult to disentangle one from another. Indeed, women living with a smoking husband (and hence exposed to ETS) may more often smoke than partners of non-smoking men. This issue has been addressed in our analyses: analyses of ETS effects are restricted to non-smoking women. The potential for ETS to confound the association between active smoking and birth weight is much weaker because doses of tobacco smoke stemming from ETS are much lower than those due to passive smoking (see also point 1.6 below).

I.2) Unfortunately, I was not able to access the supplemental material and tables 4 and 5 were truncated. The Editorial Assistant confirmed this but could not provide new tables or materials for evaluation.

R: The right part of Tables 4 and 5 were indeed missing, probably as a result of the conversion in pdf format, and we apologize for any mistake in manuscript uploading from our side. We made sure that these Tables appear in totality in the revised version. Concerning the supplemental material, it was accessible by double-clicking on the sentence "Click here to download supplemental material" on the last page of the document, at least in the version that we uploaded from the journal web site.

\section{SPECIFIC COMMENTS:}

I.3) Test for Hardy-Weinberg (in the 3 category genotypes).

R: We now report the results of Hardy-Weinberg disequilibrium test for the 2 genotypes with 3 categories in the results section (section 3.1); the gene for which an interaction has been highlighted (GSTPI) was in Hardy-Weinberg equilibrium: 
"CYP2D6 polymorphism was not in Hardy-Weinberg equilibrium $(p<0.01)$, while there was no evidence of a deviation from equilibrium for $\operatorname{GSTP1}(p=0.89)$." $(3.1, p .12, I .20)$

I.4) Discuss the potential for population stratification bias.

$R:$ This point has been added in the discussion section:

"Population stratification bias is another source of error in genetic studies. This term is used to denote confounding by an unmeasured factor (such as ethnicity) associated with the health outcome and the genetic polymorphism under study [1]. If not controlled for, this unmeasured factor may entail a bias in the estimation of the main genetic effect on the health outcome, or of gene-gene or gene-environment interactions [2]. In our cohort, both parents had to be born in Germany and to have the German nationality in order for their child to be eligible in the cohort which, given the rather stringent laws regarding citizenship at the end of the 1990s, strongly limited the proportion of parents whose family immigrated from outside Europe in the recent generations. Therefore, our population was rather homogeneous from an ethnic point of view. This makes a population stratification bias due to ethnic factors unlikely." (4.4, p.18, I.11)

I.5) The paper is exceedingly short on DNA extraction and genotyping methods. Please provide more information.

R: References on genotyping methods are provided, and we have now expanded this section as requested:

"DNA was extracted from thawed whole blood sample by use of a QIAamp Blood Kit (Qiagen) according to the "blood and body fluid protocol" recommended by the manufacturer. We used $600 \mu \mathrm{l}$ of the blood sample for DNA extraction. The 4 genes considered are implied in the metabolism of xenobiotics. GSTT1 and GSTM1 null genotypes correspond to a loss of glutathione S-transferase activity [3]. GSTP1 represents the main glutathione S-transferase isoenzyme in the lung. The nonsynonymous GSTP1 polymorphism ( $r s 1695,313 A>G$, Ile 105Val) has been associated with reduced enzyme activity and anticancer drug resistance and toxicity [4, 5]. CYP2D6 is highly polymorphic, with polymorphism 1846G $>A$ (rs1800716) causing a splicing defect that results in a non-functional protein $[6,7]$. This variant is responsible for the majority of the reduced enzyme activity found in Caucasian populations [8]. Genotyping of GSTM1, GSTT1 and GSTP1 was performed following Bauer et al. [9]: we used a multiplex PCR approach. Briefly, $10 \mathrm{ng}$ genomic DNA was amplified in a 20 $\mu \mathrm{l}$ reaction mixture containing 10 pmol of each of the following primers: GSTM1_for 5'GTGGAGACAGAAGAAGAGAAGA-3', GSTM1_rev 5'AGAGGCCAGAGCTGA TGAAGG-3', GSTT1_for 5'ACCCTGGCAGAGTTGGATGTGACC-3', GSTT1_rev 5'GTGGAAGACAGGGTGGGGATGGT-3'. As an internal positive control, the $\bar{R} O N$ gene was co-amplified with the primers RON_for 5'CTAGTGGGGAGGTGGAGCAGATA-3' and RON_rev AAGCAGGTCCAGCCCAAGAACTAA-3'. PCR was performed at $94^{\circ} \overline{\mathrm{C}}$ for $5 \mathrm{~min}$, then 38 cycles at $94^{\circ} \mathrm{C}$ for $30 \mathrm{~s}$, at $60^{\circ} \mathrm{C}$ for $30 \mathrm{~s}$, at $72^{\circ} \mathrm{C}$ for 1 min and extension at $72^{\circ} \mathrm{C}$ for $10 \mathrm{~min}$. The PCR mixture contained $1.25 \mathrm{mM} \mathrm{MgCl}_{2}, 200 \mu \mathrm{M}$ each dNTPS, 10 pmol of each primer and $1 \mathrm{U}$ BIOTAQ DNA polymerase (Bioline, Luckenwalde, Germany). We used PCR mixture without DNA as a negative control to exclude false-positive data. The multiplex PCR products were then electrophoretically analysed on a $2 \%$ ethidium bromide-stained agarose gel (QA-Agarose, Qbiogene, Heidelberg, Germany). The presence or absence of GSTM1 and GSTT1 genes was detected by the presence or absence of a 688-bp (corresponding to GSTT1) and a 378-bp (corresponding to 
GSTM1) PCR band. GSTP1 lle 105 Val polymorphism was detected by means of restriction fragment length polymorphism approach. Genomic DNA was amplified by PCR with the GSTP1_14 for 5'- CTGCCCCCGGAGCCCTTTTGTTTA3' and GSTP1_I5_rev 5' CTCGCCCCCATG ACCCGTTACTTG-3' primer pair giving a 655-bp PCR product. The PCR product was consecutively restricted by BsmAl endonuclease (Fermentas, St. Leon-Rot, Germany) for $2 \mathrm{~h}$ at $37^{\circ} \mathrm{C}$. The reaction mixture was analysed by agarose gel electrophoresis. A 3-band and 4-band restriction pattern was identified as $105 \mathrm{lle}$ and Val, respectively. For CYP2D6, we used the approach described by Hersberger et al. [10]. As a quality control procedure, we repeated the genotyping of a random sample of $3 \%$ of our study population, which showed a $100 \%$ agreement with the original genotyping." $(2.4, \mathrm{p} .8)$

I.6) As mentioned above, it seems difficult to attribute to a particular exposure what could be due to the others that are postulated to have the same mechanisms. This issue needs to be addressed.

R: This issue has been addressed in our analyses: analyses of ETS effects are restricted to nonsmoking women, so that the reported parameters quantifying ETS effects on birth weight directly or in interaction with genotypes cannot be influenced by active smoking. The potential for ETS to confound the association between active smoking and birth weight (or any interaction between active smoking and genotypes) is much weaker because doses of tobacco smoke stemming from ETS are much lower than those due to passive smoking, and because of the weak reported effect of ETS on birthweight in our population. Concerning the interactions with exposure to fine particulate matter, analyses are adjusted for active and passive smoking, as reported in the methods section so that, again, the pattern of interaction between PM2.5 and genotypes cannot be explained by active or passive smoking. If we exclude active smokers (thus reducing the population size from $n=354$ to $n=328$ ), the statistical interaction between PM2.5 and GSTP1 polymorphism is still present $(p=0.02)$.

We now mention this issue in the discussion section:

"We could control for a variety of potential confounders such as maternal size, prepregnancy weight, socio-economic status, active and passive smoking. As an alternative way to control for active smoking, we repeated the analysis among nonsmoking pregnant, and the statistical interaction between $\mathrm{PM}_{2.5}$ exposure and GSTP1 was still present $(p=0.02)$, confirming that this statistical interaction was unlikely to be explained by factors known to influence birth weight." $(4.1, \mathrm{p} .15, \mathrm{I} .35)$

1.7) Page 6 states that authors investigated change of address but on page 7 they excluded those who did change address. Why was it not possible to assign exposures to all addresses?

Reply: It was not possible to assign exposure to women who moved out during pregnancy because only the maternal address at the time of birth has been recorded upon inclusion in the cohort; for women who changed address during pregnancy, the former address has not been recorded. Using the birth address for these women would create exposure misclassification, which is the reason why we preferred to exclude them. Note that in contrast to our study, most former studies on the subject usually had no information on changes in the home address during pregnancy, and therefore had to assume that all women did not move out during pregnancy, entailing a possible bias due to exposure misclassification. This issue has been discussed in our previous publication based on this cohort (Slama et al., Env Health Perspect, 2007). 


\section{Reviewer \#2:}

2.1) The manuscript by Slama et al. presents results from a population-based study in which geneenvironment interactions for air pollution exposure on infant birthweight were examined. The strengths of the study reside in the examination of a robust and well-defined study population - the LISA cohort. The premise and study design are straightforward and the manuscript is well written overall, with conservative conclusions evolved from the study findings. The principle limitations center on the need for more informative Introduction and Discussion sections, and more detailed elaboration of the results (Tables 2 through 6).

The Introduction is exceedingly abbreviated and provides only a superficial overview of key concepts that the authors attempt to integrate in their study. The manuscript would benefit from more substantive introductory remarks on:

Air pollutants; definition, composition, forms serving as exposure sources in the LISA birth cohort the study population under investigation; Fine particulate matter definition, sizes, relationship between environmental particulate matter and smoke related particulate matter.

$\mathrm{R}$ : We now expanded the introduction regarding fine particulate matter and its sources in an urban setting:

"In cities from industrialized countries, $\mathrm{PM}_{2.5}$ are mainly derived from combustion processes such as road traffic, heating, biomass burning and specific industrial processes; additionally, a part of $\mathrm{PM}_{2.5}$ are derived from the conversion of gaseous precursors such as sulphur or nitrous oxides, ammonia or volatile organic compounds [11]. In the city of Munich, about $60 \%$ of the local emissions of the larger $\mathrm{PM}_{10}$ stem from (road and train) traffic [12], a proportion that is probably higher for $\mathrm{PM}_{2.5}$. $\mathrm{PM}_{2.5}$ are a complex mixture composed of air-suspended liquid and solid particles. From a chemical point of view, in urban sites, $\mathrm{PM}_{2.5}$ are mainly composed of secondary aerosol (ammonium nitrate and ammonium sulfate), organic matter (including many types of volatile, semivolatile and non-volatile compounds) and elemental carbon [13]." (p.5, I.41)

Regarding the study population, it is described in the methods section, which is, we believe, a more appropriate location than the introduction. Please see point 2.2) below regarding the relation between environmental $\mathrm{PM}_{2.5}$ and smoke-related PM.

2.2) What is the relationship between air pollution related fine particulate matter and particulate matter associated with active smoking or environmental tobacco smoke exposure? Authors indicate "human exposure to air pollution occurs through the same pathway as exposure to tobacco smoke [active and passive smoke exposure]"..it is unclear what they authors mean by "same pathway". What are the commonalities..as well as the differences?

R: We have now detailed this part of the introduction:

"Human exposure to combustion-related air pollution occurs through the same pathway (inhalation) as exposure to tobacco smoke; these two mixtures also share similarities in terms of granulometry of their particulate component $[14,15]$ and also in terms of chemical composition. Indeed, tobacco smoke particulate matter has an aerodynamic diameter typically in the $50-800 \mathrm{~nm}$ range [15], which covers the 10-100 nm range, corresponding to fresh traffic-related PM [14]. Many families of combustions byproducts such as volatile organic compounds (e.g., benzene) or polycyclic aromatic hydrocarbons are present in both mixtures. A notable difference is nicotine, which is present in tobacco smoke but not in traffic-related air pollution. In terms of effects on 
reproductive function, maternal exposure to each of these mixtures has been associated with decrements in term birth weight in humans $[16,17] . "$ (p.6, I.8)

2.3) What is the relationship between atmospheric particulate matter and xenobiotic metabolizing enzymes? Some perspective should be provided. What is the justification for the choice of the four genes investigated..are they of particular relevance to the type of particulate matter exposures incurred by the LISA cohort?

$\mathrm{R}$ : We have now expanded the introduction on this issue:

"The metabolism of xenobiotics can schematically be seen as a process in two phases; phase 1 usually corresponds to a functionalisation of xenobiotics, which makes them more electrophilic or nucleophilic, thus allowing a conjugation step, corresponding to the phase 2 of metabolism, which eventually leads to more hydrophilic compounds that can be more easily eliminated from the body than the parent xenobiotics. Examples of enzymes implied in phase 1 metabolism include the cytochrome P450 (CYP) superfamily. Within this superfamily, CYP2D6 belongs to the most polymorphic genes [18]. The Glutathione transferases (GST) are a family of enzymes implied in phase 2 metabolism of xenobiotics such as polycyclic aromatic hydrocarbons (PAHs), which are present in atmospheric pollution [19]. The cytosolic GSTs include 7 classes of polymorphic enzymes, among which GSTM1, GSTT1 and GSTP1. GSTM1 and GSTT1 null polymorphisms correspond to a lack of expression of the corresponding enzyme [19]." (p.4, I.35)

2.4) The authors note that only the offspring were genotyped in the present investigation. No information or discussion regarding the contribution of maternal genotype to detoxification mechanisms of air pollution/cigarette smoke is provided. Additional discussion of the role of maternal versus foetal genotype (xenobiotic metabolizing enzymes) on environmentally-induced adverse birth outcomes - particularly low birth weight - is warranted. How, if any, does the lack of maternal genotype information limit interpretation of the four genes modifying the effect of maternal exposure to particulate matter on offspring low birthweight? The authors need to clarify whether the metabolizing enzyme genotypes were determined in newborns or in six-year olds..there is an apparent discrepancy in the text.

R: Concerning the last point, genotyping was performed in blood samples collected when the children were 6 year old, as stated in the method section (section 2.4). This is unlikely to have induced bias compared to a situation in which genotyping would have been performed on biological samples collected at birth, because genetic characteristics vary little during short time periods.

So far, to our knowledge, only one gene-environment study on birth weight has simultaneously considered the genotypes of the offspring and of the mother, as shown in our table (Table 1) reviewing the gene-environment studies published so far. A correlation between the presence of heterozygosity in mothers and their children is expected, and for several of the considered genes, there is some evidence of an activity in the placenta or the foetus. Therefore, the current body of evidence does not allow to discuss the relative roles of maternal and foetal polymorphisms in xenobiotic-metabolizing genes. This issue is presented in the discussion section:

"We genotyped the newborns and not their mothers. GSTP1 has been shown to be active in foetus [20]. Some correlation between maternal and foetal heterozygosity can generally be expected [21], so that heterozygosity of the offspring may be a proxy of maternal heterozygosity. In the absence of genotyping of the mothers, and even if the statistical interaction detected 
corresponded to causal coactions, one should therefore refrain to interpret this interaction as bringing evidence for the offspring genes rather than the maternal ones being implied in the pathway between fine particulate matter exposure on foetal growth." $(4.1$, p.16, I.5)

The paragraph above also indicates that GSTP1 (the gene for which a statistical interaction with $\mathrm{PM}_{2.5}$ exposure has been highlighted) is active in the foetus [20], which means that not only maternal but also foetal enzymes could be implied in the detoxification of tobacco smoke or atmospheric pollutants.

2.5) There is a wealth of information in Table I relating to the premise and interpretation of the current study. However little of this information regarding prior findings on gene- environment interactions modifying risk of birthweight alterations following particulate matter exposure is discussed in the manuscript - begging the question as to why this has been included. Certainly the information is rich for the Introductory remarks or Discussion.

$R$ : There is actually only one previous study describing gene-environment interactions in the context of particulate matter exposure for effects on birth weight (Suh et al., Reprod Toxicol, 2007). Our original idea was to present this study and other gene-environment studies on birth weight dealing with tobacco smoke exposure in Table 1 in order to maintain the text short. We have now expanded the introduction, detailing some of the results contained in the Table, without integrally duplicating this information:

"The latter were considered in only one study based on 199 births, in which two polymorphisms of CYP1A1 gene were assessed. No interaction tests have been reported, but birth weight changes associated with $\mathrm{PM}_{10}$ exposure above the $90^{\text {th }}$ percentile (compared to below the $90^{\text {th }}$ percentile) were not clearly in favor of an effect measure modification by any of the polymorphisms considered (see [22] and Table 1 of this paper). Therefore, there is currently very limited direct evidence for genetic polymorphisms modifying the effect measure of air pollutants on foetal growth in humans. Some genes implied in the metabolism of xenobiotics have been shown to modulate the action of drugs in the body [4, 5, 23, 24], and they appear worth being considered in the context of the study of air pollution effects. (...) Some of these genes have been considered in gene-environment interaction studies on human birth weight in relation to maternal active or passive smoking. In addition to the cytochrome P450 (CYP) superfamily and the glutathione transferases (GST) family, NQO1 $(\mathrm{NAD}(\mathrm{P}) \mathrm{H}$ : quinone oxidoreductase 1) and EPHX1 (epoxide hydrolase 1) polymorphisms have also been considered (see Table 1 for a review). Hong et al. reported an increase in mean birth weight associated with exposure to passive smoking (ETS) in GSTT1 wild genotype and a decrease in mean birth weight associated with ETS exposure in GSTT1 null genotype [25]. In a case-control study, the estimated effect of ETS on mean birth weight also tended to be stronger in the offspring of mothers with GSTT1 null genotype than with GSTT1 wild genotype [26]. No clear statistical interaction have been described for polymorphisms of GSTM1 gene, and GSTP1 and CYP2D6 have so far very little been considered in this context." (p.4, I.11)

We also expanded the discussion, indicating that:

"Although quite imprecise, our results concerning GSTM1 were qualitatively in agreement with previous reports in which mothers had been genotyped in favor of ETS being associated with greater decrements in mean birth weight in GSTM1 null genotype, compared to GSTM1 present genotype [25, 26]." (4.2, p.16, I.1) 
2.6) The manuscript itself needs a more substantive discussion regarding the fact that the LISA cohort is biased in that the cohort excludes birth outcomes wherein the birthweights are below $2500 \mathrm{~g}$ (the accepted weight for low birthweight outcomes)..i.e. the linkage between particulate matter exposure/genotype and all low birthweight and very low birthweight outcomes would not have been assessed in the present study.

$\mathrm{R}$ : The exclusion of children born at term with a birth weight below $2,500 \mathrm{~g}$ is in principle an issue. We have discussed this point in our previous publication based on the same population (Slama et al., EHP, 2007), and developed a sensitivity analysis to correct for this exclusion (Slama et al., EHP, 2007). We used a similar approach in this new manuscript, and the result of the sensitivity analysis (presented in the appendix) again indicates that the exclusion of the children with a birthweight below $2,500 \mathrm{~g}$ is unlikely to have strongly biased our results. This may be explained by the fact that they only represent about $2.2 \%$ of all term newborns (see 2.6) below). In order to make these results more visible, we moved them from the online supplement to the main text.

2.7) The authors should address an apparent discrepancy in Section 4.4 wherein they cite the low birthweight incidence in the German population as less than $2.5 \%$ of term births. Incidence appears quite low; varied published statistics for the geographic area in Germany during the comparable time period of study suggest low birthweight rates approaching $6.5 \%$ of term births. Could this discrepancy affect their sensitivity analysis? In summary, the authors provide unique observations garnered from a robust and informative study cohort - regarding the potential role of xenobiotic metabolizing gene polymorphisms in modifying risk of gestational particulate matter exposure on birth weight outcomes. The manuscript would make a significant contribution to the knowledge base in reproductive toxicology and environmentally based pregnancy risks, and would benefit from the revisions as noted.

R: We are not aware of publications indicating a low birthweight ( $<2500 \mathrm{~g}$ ) rate of $6.5 \%$ among term births in Germany. This value is actually very close to the low birthweight rate among all births (including multiple births and preterm births); indeed, in Germany in 2004, the rate of low birthweight was $7.1 \%$ among all births, $5.2 \%$ among singleton births and $1.9 \%$ among live term singleton births, a population corresponding to the inclusion criteria in our cohort. Therefore, the rate of $2.2 \%$ of low birthweight babies among live term births assumed for our simulation appears very close to the national statistics (European Perinatal Health Report, appendix B, table C4, http://www.europeristat.com/bm.doc/appendix-b-data-tables.pdf). We now quote this source in the article:

"We conducted a sensitivity analysis assuming that low birthweight babies corresponded to $2.2 \%$ of singleton live term births, a figure based on the Eden mother-child cohort $[27,28]$, and close to the figure of $1.9 \%$ observed in Germany for the year 2004 [29]." (4.4, p.18, I.2)

\section{References:}

1. Wacholder S, Rothman N, Caporaso N. Population stratification in epidemiologic studies of common genetic variants and cancer: quantification of bias. J Natl Cancer Inst 2000;92:11518.

2. Wang $Y$, Localio R, Rebbeck TR. Evaluating bias due to population stratification in epidemiologic studies of gene-gene or gene-environment interactions. Cancer Epidemiol Biomarkers Prev 2006;15:124-32.

3. Hayes JD, Strange RC. Glutathione S-transferase polymorphisms and their biological consequences. Pharmacology 2000;61:154-66. 
4. Watson MA, Stewart RK, Smith GB, Massey TE, Bell DA. Human glutathione S-transferase P1 polymorphisms: relationship to lung tissue enzyme activity and population frequency distribution. Carcinogenesis 1998;19:275-80.

5. Lecomte T, Landi B, Beaune P, Laurent-Puig P, Loriot MA. Glutathione S-transferase P1 polymorphism (lle105Val) predicts cumulative neuropathy in patients receiving oxaliplatinbased chemotherapy. Clin Cancer Res 2006;12:3050-6.

6. Kagimoto M, Heim M, Kagimoto K, Zeugin T, Meyer UA. Multiple mutations of the human cytochrome P450IID6 gene (CYP2D6) in poor metabolizers of debrisoquine. Study of the functional significance of individual mutations by expression of chimeric genes. J Biol Chem 1990;265:17209-14.

7. Gough AC, Miles JS, Spurr NK, Moss JE, Gaedigk A, Eichelbaum M, et al. Identification of the primary gene defect at the cytochrome P450 CYP2D locus. Nature 1990;347:773-6.

8. Marez D, Legrand M, Sabbagh N, Guidice JM, Spire C, Lafitte JJ, et al. Polymorphism of the cytochrome P450 CYP2D6 gene in a European population: characterization of 48 mutations and 53 alleles, their frequencies and evolution. Pharmacogenetics 1997;7:193-202.

9. Bauer M, Herbarth O, Aust G, Hengstler JG, Dotzauer A, Graebsch C, et al. Expression patterns and novel splicing variants of glutathione-S-transferase isoenzymes of human lung and hepatocyte cell lines. Cell Tissue Res 2006;324:423-32.

10. Hersberger M, Marti-Jaun J, Rentsch K, Hanseler E. Rapid detection of the CYP2D6*3, CYP2D6*4, and CYP2D6*6 alleles by tetra-primer PCR and of the CYP2D6*5 allele by multiplex long PCR. Clin Chem 2000;46:1072-7.

11. Pope CA, 3rd, Dockery DW. Health effects of fine particulate air pollution: lines that connect. J Air Waste Manag Assoc 2006;56:709-42.

12. Regierung von Oberbayern. Luftreinhalteplan fu $\square \mathrm{r}$ die Stadt Mu $\square$ nchen. Munich (Germany), 2004, (Department (Government Body no. Section). http://www.muenchen.de/cms/prod1/mde/ de/rubriken/Rathaus/70 rgu/04 vorsorge schutz/l uft/pdf/luftreinhalteplan.pdf

13. Krzyzanowski M, Kuna-Dibbert B, Schneider J eds. Health Effects of Transport-related Air Pollution. Copenhagen: World Health Organization, Regional Office for Europe, 2005.

14. Schauer JJ, Kleeman MJ, Cass GR, Simoneit BR. Measurement of emissions from air pollution sources. 5. C1-C32 organic compounds from gasoline-powered motor vehicles. Environ Sci Technol 2002;36:1169-80.

15. Kleeman MJ, Schauer JJ, Cass GR. Size and composition distribution of fine particulate matter emitted from wood burning, meat charbroiling, and cigarettes. Environ Sci Technol 1999;33:3516-23.

16. Lindley AA, Becker S, Gray RH, Herman AA. Effect of continuing or stopping smoking during pregnancy on infant birth weight, crown-heel length, head circumference, ponderal index, and brain:body weight ratio. American Journal of Epidemiology 2000;152:219-25.

17. Slama R, Darrow LA, Parker JD, Woodruff TJ, Strickland M, Nieuwenhuijsen M, et al. Atmospheric Pollution and Human Reproduction: Report of the Munich International Workshop. Environ Health Perspect 2008;116:791-8.

18. Rodriguez-Antona C, Ingelman-Sundberg M. Cytochrome P450 pharmacogenetics and cancer. Oncogene 2006;25:1679-91.

19. Hayes JD, Flanagan JU, Jowsey IR. Glutathione transferases. Annu Rev Pharmacol Toxicol 2005;45:51-88.

20. Raijmakers MTM, Steegers EAP, Peters WHM. Glutathione S-transferases and thiol concentrations in embryonic and early fetal tissues. Hum Reprod 2001;16:2445-50.

21. Mitton JB, Schuster WS, Cothran EG, De Fries JC. Correlation between the individual heterozygosity of parents and their offspring. Heredity 1993;71 ( Pt 1):59-63.

22. Suh YJ, Kim BM, Park BH, Park H, Kim YJ, Kim H, et al. Cytochrome P450IA1 polymorphisms along with $\mathrm{PM}(10)$ exposure contribute to the risk of birth weight reduction. Reprod Toxicol 2007.

23. Mcllwain CC, Townsend DM, Tew KD. Glutathione S-transferase polymorphisms: cancer incidence and therapy. Oncogene 2006;25:1639-48.

24. Zhou SF, Liu JP, Chowbay B. Polymorphism of human cytochrome P450 enzymes and its clinical impact. Drug Metab Rev 2009;41:89-295.

25. Hong YC, Lee KH, Son BK, Ha EH, Moon HS, Ha M. Effects of the GSTM1 and GSTT1 polymorphisms on the relationship between maternal exposure to environmental tobacco smoke and neonatal birth weight. J Occup Environ Med 2003;45:492-8. 
26. Wang X, Zuckerman B, Pearson C, Kaufman G, Chen C, Wang G, et al. Maternal cigarette smoking, metabolic gene polymorphism, and infant birth weight. JAMA 2002;287:195-202.

27. Drouillet $P$, Kaminski M, De Lauzon-Guillain B, Forhan A, Goua V, Thiébaugeorges $O$, et al. Association between maternal fish and shells consumption before pregnancy and fetal growth: evidence for an association in overweight women. The "EDEN mother-child" cohort (study of pre and early postnatal determinants of the child's development and health). Paediatric and perinatal epidemiology 2008:1-9.

28. Slama R, Thiebaugeorges O, Goua V, Aussel L, Sacco P, Bohet A, et al. Maternal personal exposure to airborne benzene and intrauterine growth. Environ Health Perspect 2009;117:1313-21.

29. EURO-PERISTAT Project. European perinatal health report. 2008, (Department (Government Body no. Section). http://www.europeristat.com/bm.doc/appendix-b-data-tables.pdf 